\title{
Methods for small area population forecasts: state-of-the-art and research needs
}

\author{
Tom Wilson ${ }^{1}$ \\ Irina Grossman ${ }^{2}$ \\ Monica Alexander ${ }^{3}$ \\ Phil Rees ${ }^{4}$ \\ Jeromey Temple 5
}

Version 2. 4th August 2021.

1. Corresponding author. Address: Melbourne School of Population and Global Health, The University of Melbourne, 207 Bouverie St, Melbourne, Vic 3010, Australia

Email: wilson.t1@unimelb.edu.au

ORCID: https://orcid.org/0000-0001-8812-7556

2. Melbourne School of Population and Global Health, The University of Melbourne, Australia ORCID: https://orcid.org/0000-0002-5761-6194

3. Departments of Statistical Science and Sociology, University of Toronto, Canada ORCID: https://orcid.org/0000-0002-8135-3435

4. School of Geography, University of Leeds, UK

ORCID: https://orcid.org/0000-0002-4276-9091

5. Melbourne School of Population and Global Health, The University of Melbourne, Australia ORCID: https://orcid.org/0000-0002-2819-2863 


\begin{abstract}
Small area population forecasts are widely used by government and business for a variety of planning, research and policy purposes, and often influence major investment decisions. Yet the toolbox of small area population forecasting methods and techniques is modest relative to that for national and large subnational regional forecasting. In this paper we assess the current state of small area population forecasting, and suggest areas for further research. The paper provides a review of the literature on small area population forecasting methods published over the period 2001-2020. The key themes covered by the review are: extrapolative and comparative methods, simplified cohort-component methods, model averaging and combining, incorporating socioeconomic variables and spatial relationships, 'downscaling' and disaggregation approaches, linking population with housing, estimating and projecting small area component input data, microsimulation, machine learning, and forecast uncertainty. Several avenues for further research are then suggested, including more work on model averaging and combining, developing new forecasting methods for situations which current models cannot handle, quantifying uncertainty, exploring methodologies such as machine learning and spatial statistics, creating user-friendly tools for practitioners, and understanding more about how forecasts are used.
\end{abstract}

\title{
Key words
}

Population forecasts; small area; literature review; research needs 


\section{Introduction}

Small area population forecasts are used by government and business for many purposes, including planning future service provision, infrastructure, housing, market analysis, policy development, and research. For example, they inform decisions about whether to build a new school or hospital, assist companies to determine where potential markets are expanding, provide input data for other models, such as those projecting transport use, water demand, or numbers of households, and in some countries directly influence the redrawing of electoral boundaries. Decisions making use of small area forecasts can involve substantial investments and affect the provision of essential services to local communities. In addition, in situations where the latest population estimates are out of date, forecasts sometimes have to be used as interim population estimates or nowcasts.

Despite these important uses, small area forecasts remain the poor cousin of forecasts at the national and large subnational region scales, which have benefitted from much more research on methods and data preparation (e.g., Booth, 2006; Mazzuco \& Keilman, 2020). Unfortunately, existing cohort-component projection models for countries and large subnational regions, and accompanying fertility, mortality and migration forecasting methods (e.g., Li \& Lee, 2005; Raymer et al., 2006; Shang \& Booth, 2020), are often unsuitable for small areas. Difficulties include less detailed and poorer quality demographic data (due to geocoding inaccuracy, imputation, data adjustment/suppression, among others), short time series of datasets due to boundary changes, often erratic demographic trends, zero cell counts, and random noise in the data which masks underlying patterns. In addition, the populations of small areas located in growing urban areas are strongly influenced by changes in the dwelling stock, which are not easily handled by standard cohort-component models. In practice, many small area forecasts are produced using methods which have undergone little development over the last few decades. Not surprisingly, given the challenges of data, methods, and the variability and randomness inherent in small area populations, forecasts for small areas tend to suffer from considerably higher population forecast errors than those for larger subnational regions and countries (e.g., Rayer, 2008; Tayman, 2011; Wilson \& Rowe, 2011). Overall, errors tend to increase as population size decreases, with errors rising rapidly once population size declines below about 10,000 (Wilson et al., 2018).

Because of these challenges, and the importance of small area projections across the public and private sectors, it is useful to undertake an assessment of the current state of small area population forecast methodology, and offer some suggestions for research to extend and build on 
current methods, and fill important gaps. Existing reviews of population forecasting methods tend to focus mostly on the national scale (e.g., Alho, 2015; Booth, 2006), or national and subnational regional scales (e.g., Rees et al., 2015; Wilson \& Rees, 2005), or do include small area forecasting but are in need of updating and extending (e.g., Bell, 1997; Rayer 2015; Wilson, 2011).

This paper presents a review of the literature on small area population forecasting methods, covering items published over the 20 years 2001 to 2020 inclusive. Primarily we focus on the academic literature, but also include published methodological reports by statistical offices where they contribute novel methods. The scope of the review is limited to small area population forecasting models and methods for preparing forecast assumptions, but not associated topics, such as the geographical conversion of historical data to consistent boundaries prior to the preparation of forecasts (e.g., Norman et al, 2003; Simpson, 2002; Vasan et al., 2018), or the evaluation and quality assurance of forecasts (e.g., Rees et al., 2019; Wilson, 2017a). Nor do we cover derived small area forecasts or those for population sub-groups, such as school enrollment, ethnic group, or living arrangement and household type forecasts (e.g., Feng et al., 2020; GLA, 2018; Grip \& Grip, 2020; Nawaz et al., 2020). These topics would benefit from separate dedicated reviews. Later in the paper we identify research needs and make some suggestions for research avenues which we believe are worth exploring to generate more accurate, informative, and useful small area population forecasts.

There is no widely accepted definition of a 'small area' in the demographic literature (Rayer, 2015). Sometimes the term is used to describe geographies for which there is limited demographic data available (however this might be defined); or a particular population threshold might be specified. We use the term to refer to areas with populations under 100,000 , although this cut-off is to some extent arbitrary. We also include grid cells under $25 \mathrm{~km}^{2}$ or $0.05 \times 0.05$ degrees latitude and longitude in area. Examples of small areas include census tracts (US and Canada), electoral wards (UK), and SA2 areas (Australia and New Zealand). Strictly, in geographically large countries with concentrated population distributions 'small areas' can be huge in area and might be more accurately described as geographical units containing small populations. Population is defined as the usually resident population, to be consistent with estimates and forecasts produced by national statistical offices, rather than de facto populations (the number of people present in an area at a particular time irrespective of whether they are usual residents or visitors). 
We also use the term 'forecasts' throughout the paper but acknowledge that some small area forecasts are labelled 'projections' by their creators who emphasise that their numbers are not intended to be forecasts but simply the outcome of selected assumptions and models. Projections are often defined as a calculation of future population based on chosen assumptions about the future drivers of population change (which may or may not be plausible), whereas a forecast is deemed the most likely future. However, for consistency and because most users tend to interpret projections as forecasts, we primarily use the term 'forecasts' here.

Following this introduction, we briefly describe the approach taken in undertaking this review (section 2). Section 3 sets out key themes of the surveyed literature in separate sub-sections followed by a summary of the main findings, while section 4 outlines priority research areas and suggests potential avenues for further investigation. An annotated bibliography of literature included in the review is provided in the Supplementary Information accompanying the paper. 


\section{Literature search and selection}

For this review, we searched for journal papers, book chapters, and reports which:

(i) contained details on forecasting methods and approaches

(ii) were for small areas, and

(iii) were published between 1st January 2001 and 31st December 2020.

We included literature which focused on forecasting the components which directly feed into small area population forecasts, such as fertility, mortality and migration rates. We also included methods for quantifying the uncertainty of small area population forecasts.

Our approach to searching the literature on small area population forecasting methods made use of several information sources. First, we searched for papers on Google Scholar using Harzing's Publish or Perish (as it allows search results to be exported; Harzing, 2007), JSTOR, Scopus, Web of Science, Springer, Emerald, Wiley, Gale, PubMed, and the arXiv preprint server. Search terms used were: population projection, population forecast, population prediction; small area, local area, grid square, gridded, spatial, sub-national population, sub-regional population, small area population, ward-level population, county-level population, population project* (where * refers to any other letters), population predict*, and population forecast* and additional terms used to find articles on estimating the components of small area population projections included: age-specific migration, age-specific mortality, age-specific fertility, fertility, age-profile, estimating, and estimation.

Second, we followed up references in selected papers which appeared to focus on small area population forecasts. Third, we added our own papers on small area forecasting which we have collected over the years. We created an annotated bibliography and drafted a brief summary of up to 100 words of the main points for each of the selected papers. Finally, we approached the corresponding authors of these papers and asked them to check over our draft summaries and correct them if necessary. We also asked if there were any other papers within the scope of the review which we may have missed. A total of 51 authors were contacted and 20 summaries were revised. Following consultations with the authors, a further 6 papers were added to the review and summarised in the annotated bibliography. The final total number of papers included in the review is 84 . 


\section{Small area population forecasting methods, 2001-2020}

The literature on small area population forecasting methods from the last two decades is presented in the following ten sub-sections, categorised by type of forecasting method or approach. Any categorisation such as this is to some extent subjective, and there is inevitably research which can be categorised under more than one theme.

\subsection{Extrapolative and comparative methods}

Simple extrapolative models are generally applied to project population totals rather than ageand sex-specific populations. Although atheoretical and based solely on past trends, their strengths include minimal data requirements, simple and quick calculation, and accuracy which is often comparable to, or better than, more detailed and complex methods (Smith et al. 2013: chapter 8). Comparative (or ratio) methods create a small area projection through a relationship with an independent projection for a larger geographical area (e.g., for a state, large region, or country), and are also generally applied just to population totals. Many of these simple methods date back many decades (Isserman, 1977; Openshaw \& Van Der Knaap, 1983; Pearl \& Reed, 1920; Pritchett, 1891; Schmitt \& Crosetti, 1951; Smith, 1987; White, 1954) though they became less popular in the later decades of the 20th century as computing power increased and more complex models gained prominence. However, over the last decade or so, a number of studies have re-examined the properties of existing simple extrapolative and comparative methods for local and small area forecasts, and introduced some new variants.

To create grid square population forecasts across the world, Hachadoorian et al. (2011) tested two simple methods, one which applied a projected share of national population (shift-share), and the other a constant share of national population growth. The forecasts covered the period 1995-2025. Over the long run both methods were found to suffer problems, such as negative populations and trend reversals. Xanthos et al. (2013) tested several share-of-population and share-of-population-growth models over 10 year historical periods to small areas in a region of Greece, finding that the lowest errors ${ }^{1}$ were obtained from the constant share-of-population model.

\footnotetext{
${ }^{1}$ We report relatively few quantitative error values in this paper. Unfortunately, there is inconsistency in error measures used, variation in forecast horizons, and often no overall summary error measure reported (instead, a large number of errors for different parts of the evaluation). We address this issue in the 'research needs' section later.
} 
Rayer (2008) conducted a comprehensive evaluation of simple methods for forecasting the total populations of 2,482 counties in the US. 'Forecasts' over historical periods were calculated for multiple jump-off years and projection horizons. Among the five individual extrapolative and comparative models tested, linear extrapolation proved marginally the most accurate, but the constant share-of-population model did not perform particularly well. At 10 and 20 year horizons mean errors did not vary greatly between methods; however, after 30 years the exponential extrapolation gave by far the highest mean errors. The accuracy and characteristics of several extrapolative and comparative methods were also analysed as part of a study by Wilson (2015). Retrospective small area forecasts were produced for a 10 year horizon and compared to actual population estimates in Australia, New Zealand, and England \& Wales. Of the methods evaluated, the best models were found to be a modified share-of-growth model (calculated as shares of national base period growth using only positive shares, with negative shares set to zero), and a constant share-of-population model. Methods susceptible to producing negative populations or runaway growth in the long run were identified (linear, projected share-ofpopulation, constant share-of-growth, exponential, and constant growth rate difference).

Hauer et al. (2015) employed a housing-unit model to forecast the total populations of subcounty areas of Georgia, USA, with the number of housing units being projected by a Linear/Exponential model (linear if base period growth was positive; exponential if it was negative) fitted to a 70 year base period of dwelling counts. The advantage of this composite model is that negative populations and runaway growth are avoided. Linear/Exponential extrapolation was also applied by Hauer et al. (2016) to forecast the populations of census block groups in US counties expected to be severely impacted by sea level rises in coming decades. These forecasts were then used in further work which modelled internal migration flows out of coastal areas which may occur due to sea level rise (Hauer, 2017). Baker et al. (2008) projected populations via the housing unit method, forecasting dwelling numbers using a logistic curve because it mimics the growth in dwelling stock as new housing estates are developed. In their application to urban census tract populations in New Mexico, USA, the authors concluded that this approach worked well over a short-term forecast horizon.

Also included under the general heading of extrapolation are time series models. An example can be found in Athukorala et al. (2010), who forecast the total populations of two local government areas in Queensland, Australia, using Autoregressive Integrated Moving Average (ARIMA) models. Walters and Cai (2008) evaluated the Holt-Winters (exponential smoothing), ARIMA, and linear and exponential extrapolative models. They created several sets of retrospective forecasts for US states and local areas in Virginia, USA. The authors conclude that both Holt- 
Winters and ARIMA models are roughly comparable in accuracy to cohort-component models, and that Holt-Winters is preferable to ARIMA because of its more intuitive nature. Nonetheless, time series models are more complex and time-consuming to implement than simple extrapolative or comparative models, and usually require more data (Tayman et al. 2007); they are not commonly used to forecast small area populations.

\subsection{Simplified cohort-component methods}

The simplified version of the cohort-component model, the Hamilton-Perry model (Hamilton \& Perry, 1962), has experienced a revival for forecasting local and small area populations in recent years (Baker et al., 2017; Smith et al., 2013 pp. 176-179). In this model, the population is still projected by cohort, but not by demographic components. Instead, the population of a cohort at the start of a projection interval is multiplied by a Cohort Change Ratio to obtain the aged-on cohort population at the end of the interval. Young childhood populations can be forecast using Child/Woman Ratios. The model yields age-specific population forecasts but does not require fertility, mortality or migration input data, making it applicable in data-limited circumstances which prevent the use of regular cohort-component models. The consequent limitation of this model is that fertility, mortality and migration assumptions cannot be specified, and projected demographic components of change are not produced (although Baker et al. (2017, chapter 13) decompose cohort change into mortality and net migration components). Most published applications have been in the USA where small area demographic component data is limited.

The Hamilton-Perry model has been implemented in various ways, and with some interesting extensions. Swanson et al. (2010) used it to forecast the populations of census tracts and block groups, adjusting cohort change ratios to match population estimates early in the forecast horizon, and applying ceiling and floor limits to prevent growth becoming too high or too negative. Baker et al. (2014) used it to project the populations of urban census tracts with spatial weighting applied to preliminary forecasts. This was implemented by averaging preliminary forecasts for each census tract with those of its neighbours as defined by rook and queen contiguity matrices. The spatially-weighted forecasts were found to be more accurate than the original unweighted forecasts. In related work, Inoue (2017) tested alternative ways of smoothing small area cohort change ratios and child/woman ratios. In an application to small areas of Japan, it was found that smoothing which combined both local ratios and ratios from the larger prefecture in which it was located improved the quality of forecasts relative to not applying smoothing. 
Tayman and Swanson (2017) evaluated several ways of adjusting cohort change ratios and child/woman ratios throughout the forecast horizon. One option averaged these ratios over two 10 year inter-censal intervals, while a second involved extrapolating the difference in ratios over the two 10 year intervals of the base period. A third option modified local ratios over time to the same extent as ratios calculated from independent forecasts for a larger region. When applied to counties in Washington State and census tracts in New Mexico, the third option gave the most accurate forecasts.

Studies have also assessed unconstrained versus constrained Hamilton-Perry forecasts. Baker et al. (2020) evaluated the Hamilton-Perry model for census tracts across the US, with one set constrained to linear extrapolations of total population, and another remaining unconstrained. The constrained set proved more accurate. Similarly, Wilson (2016) tested several forms of cohort-component model for local areas in Australia, including the standard Hamilton-Perry model and a version constrained to total populations from an extrapolative model. The latter proved more accurate. This constrained Hamilton-Perry model gave only slightly less accurate forecasts by age (except at the highest ages) than versions of the cohort-component model incorporating migration.

Hauer (2019) created population forecasts by age, sex and race for all counties of the US for 2020-2100 using the Hamilton-Perry model. He introduced one key variation: for county/race populations which were declining he applied cohort change ratios, but for growing populations he used cohort change differences (i.e., absolute numbers). This is similar to the linear/exponential composite model noted earlier. Cohort change ratios and differences were forecast using $\operatorname{ARIMA}(0,1,1)$ models, and all population forecasts were constrained to those from the Shared Socioeconomic Pathways for the US as a whole. An evaluation of forecasts from 2000 to 2015 revealed the composite cohort change ratio/difference approach to be slightly more accurate than using cohort change ratios or differences alone.

Dockery et al. (2020) proposed a type of cohort model to project small Indigenous populations in rural and remote regions by sex and five year age group. Although reference is not explicitly made to the Hamilton-Perry model, their approach is effectively a Hamilton-Perry model in which the population is projected using cohort change differences. The unique feature is that cohort change is projected with a regression model which uses a range of demographic, social and geographic variables. A regression model is also used to project the number of 0-4 year olds based on population numbers in older childhood ages. The method was applied to produce five 
year horizon projections of small area Indigenous populations by age and sex in regional and remote parts of Australia.

\subsection{Model averaging and combining}

The benefits of model averaging and combining were highlighted in the statistics and forecasting literature several decades ago (e.g., Bates \& Granger, 1969; Clemen, 1989) but until quite recently such approaches were uncommon in demographic forecasting (though see, for example, Isserman, 1977, and Smith \& Shahidullah, 1995 for explorations of some of these techniques). Averaging and combining are often found to reduce errors. This is thought to be because they draw on a wider amount of information than any one model, and because errors in different directions from individual models offset one another to some extent (Goodwin, 2009).

For small area population forecasts, evaluations of averaged or composite models generally find that they perform quite well. Rayer (2008) created retrospective total population forecasts for US counties using 5 simple methods, and found that a mean of all five methods and a trimmed mean based on the three remaining forecasts after excluding the highest and lowest forecasts, produced mean errors comparable to the best individual methods, or better. For subcounty areas in Florida, Rayer and Smith (2010) similarly found that averaged forecasts and trimmed means performed well. Composite models, where different methods are applied to areas based on their population size and growth rate, were found to reduce errors a little further. The Bureau of Economic and Business Research at the University of Florida has employed a trimmed mean method to produce its annual county population forecasts in Florida for some time (e.g., Rayer \& Wang, 2020).

Averages of extrapolative and comparative models for forecasting small area population totals were found to result in modest gains in accuracy in Australia, New Zealand, and England \& Wales (Wilson, 2015). The best averaged models mostly contained a constant share-ofpopulation model (share of national population) and at least one type of share-of-growth model (national population growth), suggesting that a projection which takes an average of national and local trends is beneficial. The best composite models, based on population size and growth rate categories, also gave errors slightly better than the best individual models. Further assessment of the averaged constant share-of-population / share-of-growth model was reported in Wilson (2017b). It was applied at various geographical scales over several 10 year forecast horizons. Median Absolute Percentage Errors (MedAPE) were low, and consistently lower than those from linear extrapolation. 
Reinhold and Thomsen (2015) evaluated several versions of cohort-component model applied to districts in Lower Saxony, Germany. Retrospective forecasts were created for a 10 year horizon and compared to population estimates. The models tested consisted of the cohort-component with and without migration, and the cohort-component model constrained to total populations from simple linear, no change, projected share-of-population, and constant share-of-population models. The mean of all forecasts gave slightly lower errors than any individual method for both total population and age-specific populations. A similar evaluation of several versions of cohortcomponent model applied to local government areas in New South Wales, Australia, was undertaken (Wilson, 2016). The cohort-component models tested included those with bi-regional migration flows, net migration numbers, net migration rates, a composite model (using net migration numbers for positive net migration and rates if negative), and the Hamilton-Perry model. A second set of forecasts were produced where the cohort-component forecasts were constrained to total populations from an averaged extrapolative model. The constrained forecasts proved much more accurate than the unconstrained forecasts, and the bi-regional model produced the most accurate age-specific forecasts by a small margin, followed by the composite net migration model.

\subsection{Incorporating socio-economic variables and spatial relationships}

Researchers have argued that demography is an inherently spatial social science (e.g., Matthews $\&$ Parker, 2013; Voss, 2007), but small area demography is especially so. Demographic trends and patterns in small areas do not occur in isolation, but are geographically connected to other areas - most obviously through migration and short-term mobility, but also by possessing characteristics which are often similar or identical to nearby areas, such as social norms, culture, politics, housing types, environment, laws and regulations, etc. As summarised by Tobler (1970: p. 236) "everything is related to everything else, but near things are more related than distant things." In demography more generally, spatial modelling and analysis have grown in importance over the last decade or two (e.g., Chi \& Zhu, 2008; Gu et al, 2020; Matthews \& Parker, 2013). Yet only a few contributions to small area population forecasting incorporate explicitly spatial relationships (other than migration flows) in their modelling.

Chi (2009) investigated whether forecasts of sub-county total populations could be improved by incorporating variables correlated with population change in the modelling. Four regression models were applied to forecast the populations of minor civil divisions in Wisconsin which included explanatory variables related to an area's demographic and socioeconomic characteristics, transport accessibility, natural amenities, and land development characteristics. 
Comparisons with four simple linear and exponential extrapolative models reveal the regression approach does not outperform extrapolation. Chi and Voss (2011) then created and evaluated regression models which incorporate variables from neighbouring areas. In their "spatiotemporal regression forecasting approach" they selected the seven nearest neighbouring areas and weighted variables according to inter-centroid distances. The neighbour variables included lagged population growth rates and a selection of social, economic and environmental characteristics. Although conceptually appealing, the regression models did not produce lower errors than a simple extrapolative model when applied to minor civil divisions in Wisconsin, over the 1990-2000 period. Chi et al. (2011) applied these regression models to census tracts in the city of Milwaukee to assess whether they worked better in an urban setting. In this study, Mean Absolute Percentage Errors were found to be slightly lower than those of several simple extrapolative models. In later work, a geographically-weighted regression approach was proposed and tested (Chi \& Wang, 2017). When applied to minor civil divisions in Wisconsin, the geographically-weighted regression model was found to be slightly less accurate than several simple extrapolative forecasts.

Other researchers have applied spatial weighting to the results of population forecasts or to input assumptions. Baker et al. (2014) created three sets of census tract forecasts using the HamiltonPerry model, two which used initial projections for each census tract averaged with those of its neighbours. This approach yielded lower errors than not applying spatial averaging. Inoue (2017), also using the Hamilton-Perry model, smoothed cohort change ratios and child/woman ratios for small areas by incorporating ratios for the prefecture in which each small area was located. This lowered errors relative to forecasts with no smoothing.

\subsection{Housing-led population projections}

At the small area scale, population size and composition are often closely associated with the number and types of dwellings (Bell, 1997; Dittgen \& Dutreuilh, 2005; Franzén \& Karlsson, 2010; Myers, 1990). The housing-unit method has long been used by demographers to create population estimates (Bryan, 2004; Swanson \& Tayman, 2012) as well as forecasts (Bell, 1997; Foss, 2002). The total population is calculated as the number of private dwelling units multiplied by the proportion of dwellings occupied by usual residents multiplied by average household size, plus the number of people living in non-private (institutional) dwellings. The method is computationally simple and, with accurate estimates of the component terms, it provides accurate population numbers. A limitation is that it only generates population totals (i.e., no age and sex detail), although these totals can be produced for different dwelling types. In forecasting 
applications, the accuracy of the housing unit model depends on the reliability of recent data and assumptions made about each of the individual inputs to the model. In many urban areas, planning policies and systems mean that the future number of private dwellings which will be built over the next 5 or 10 years is known with a reasonable degree of certainty. Future change in average household size and the proportion of dwellings occupied may be harder to estimate.

The housing-unit model regularly proves a useful tool for researchers, often in combination with other models. As noted earlier, Baker et al. (2008) used it for census tract population forecasts, employing a logistic curve to model the growth of dwellings, while Hauer et al. (2015) used it for sub-county area forecasts, applying a Linear/Exponential model to forecast dwelling numbers. The housing-unit model is also regularly used by government, academic, and private sector demographers to produce local and small area population forecasts (e.g., Portland State University Population Research Center, 2015; QGSO, 2018).

A mixed housing-unit/cohort-component approach was taken by Dittgen and Dutreuilh (2005) in preparing population forecasts for Paris. Although details of the model are not provided, the description suggests that they created a cohort-component model which separates out migration affecting existing dwellings from the population moving into new dwellings. The number of new dwellings is multiplied by a projected average household size, and then disaggregated using an assumed age-sex profile. The additional population is then added to the population produced by the cohort-component model. A similarly adapted cohort-component model, which handles population in existing and new dwellings separately, is described by Hansen (2010).

An alternative is to create dwelling-led forecasts which combine forecasts of future dwelling numbers with a headship rate or propensity household model together with a cohort-component model. The dwelling input consists of future numbers of dwellings occupied on a usual residence basis plus the number of persons living in institutional accommodation. However, average household size is not an input assumption, but one of the model outputs. This allows changes in population age structure to influence average household size. Marshall and Simpson (2009) and Simpson (2017) describe how dwelling-led projections for local areas in the UK-based POPGROUP software are produced in this way. Migration is adjusted in volume (but not age pattern) so that population and household forecasts are consistent with assumed dwelling numbers. The POPART local area population forecasting program takes a similar approach, adjusting inward and outward migration flows in an iterative calculation scheme (and indirectly adjusting numbers of births and deaths as well as populations-at-risk change) to match future occupied private dwelling numbers (Wilson, 2014). 
Franzén and Karlsson (2010) propose quite a different approach in which small area migration rate age profiles for the cohort-component model are not based on noisy local data, but derived from national data and the housing mix of a small area. The key assumption is that people living in certain dwelling type/tenure categories share the same demographic characteristics throughout the country, so that national data on internal migration by dwelling type can be used at the small area scale. In an application to Sweden, the authors identified 33 housing categories using cluster analysis, all with specific in- and out-migration age profiles. For small area forecasts, the authors suggest weighting the housing-specific migration age profiles by the dwelling composition of each small area.

\section{6. 'Downscaling' and disaggregation approaches}

Research on 'downscaling' (or disaggregating) national or large regional population forecasts to small areas has emerged over recent years, primarily as part of the literature on the Shared Socioeconomic Pathways (scenarios of macro-scale global social, economic and natural systems change to facilitate studies of adaptation to climate change; O'Neill et al. 2014). In practice, the methods often involve a mixture of national forecast disaggregation and small area forecasting, but always with the application of top-down constraining. This stream of research appears to be relatively distinct from other work in small area population forecasting, and is generally more focused on 'big picture' global patterns of population with spatial detail for many decades into the future, whereas most other small area forecasting studies are more geographically and temporally limited in extent and have an applied planning and policy focus. Many of the downscaling methods start with national-level population forecasts produced by the United Nations Population Division, the International Institute for Applied Systems Analysis (IIASA), or national statistical offices, and small area grid square population estimates produced as part of the Gridded Population of the World datasets (https://sedac.ciesin.columbia.edu/). Given the 'big picture' emphasis and huge amount of data involved in these studies, most use assumptions which considerably simplify reality. Many models in the 'downscaling' literature have not undergone comprehensive forecast accuracy assessments.

Some studies apply relatively simple methods. For example, Breidenbach et al. (2019) created age-sex population forecasts for $1 \mathrm{~km}^{2}$ grid squares of Germany for the period 2015 to 2050 . They applied a cohort-component model for each grid square, assuming national mortality rates for each area, area-specific fertility rates, zero internal migration, and net international migration distributed according to the population distribution. Merkens et al. (2016) created small grid 
square forecasts of coastal population totals across the world from 2010 to 2100 . Their method divided each country into 4 'zones' (coastal-urban, coastal-rural, inland-urban, and inland-rural) and assumed recent growth rate differences between zones would continue, with forecasts constrained to independent national population and urbanisation forecasts. Grid square forecasts were created by assuming the grid square population will grow at the same rate as the zonal population.

Other studies have used more complex methods involving multiple models. McKee et al. (2015) prepared small grid square population forecasts for the contiguous USA. First, they created county forecasts by age and sex using a cohort-component model with net migration rates. Second, constraining to US Census Bureau State and national forecasts was applied. And then the county forecasts were disaggregated to grid squares according to a "potential development coefficient" based on a set of variables which included land use, roads, urban accessibility, and current population. Boke-Olén et al. (2017) took a similar approach to create gridded population forecasts for Africa. National scale forecasts from IIASA were disaggregated using spatially detailed data on roads, water bodies, country borders, and distance to urban centres. Chen et al. (2020) applied various machine learning algorithms to forecast the populations of tiny $100 \mathrm{~m}^{2}$ grid squares for China for the period 2015 to 2050.

Zoraghein and O'Neill (2020a, 2020b) also created small area population forecasts for the USA, though for $1 \mathrm{~km}^{2}$ grid squares and for population totals only. Existing State population forecasts were downscaled to grid squares using a gravity-type model, specified separately for urban and rural areas. Forecast population growth was allocated to each grid square proportional to its assumed 'suitability for growth' based on several socio-economic, land use and environmental variables, while forecast population decrease was distributed according to the inverse of suitability.

Some other studies involving disaggregation to small areas fall outside the climate-themed literature. They take a variety of approaches. Stimson et al. (2012) describe the creation of a large-scale urban model to forecast population, housing, employment and other socio-economic variables for the region of South East Queensland, Australia. Small area population forecasts are closely related to the future pattern of dwelling growth. Future dwelling growth for the region as a whole is allocated to small grid squares using a model which mimics the land development process and considers residential land availability, proximity to existing development, and the accessibility of local areas to services and transport. In New Zealand, Cameron and Cochrane (2017) also used a detailed land-use model, the Waikato Integrated Scenario Explorer (WISE), to 
disaggregate population forecasts for larger regions created by a cohort-component model to smaller area units. Several regression models were fitted to distribute population. An evaluation over the recent past compared the forecasts with those of two simple models, finding the authors' forecasts were competitive with one of the simple models and slightly less accurate than the other.

Other approaches apply a variety of disaggregation techniques. Li and Corcoran (2011) evaluated alternative dasymetric methods to distribute population forecasts for the region of South East Queensland, to small areas based on their dwelling density category, with each density category assigned a proportion of regional population growth. They concluded that a method involving four density classes produced the best results. The classic shift-share method was adapted by Alonso González et al. (2015) to disaggregate regional age-sex population forecasts in Spain to small areas. Local area population growth is modelled as the function of three effects: regional total population growth (regional effect), regional change by age group (age effect), and local area age-specific growth (local effect). The data requirements are modest and the calculations relatively simple.

Several studies involve the disaggregation of outputs of cohort-component models applied to demographic data from higher geographies. In Kanaroglou et al. (2009), the authors develop a model which combines a multiregional cohort-based demographic model and an aggregated spatial multinomial logit model to forecast small area populations. Migration flows are estimated by disaggregating migration data available at the municipal level by using migrant and destination area characteristics (e.g., migrant's age, number of schools, distance to city centre). Jiang et al. (2007) present a Hidden-Markov model based small area population forecasting method which incorporates a hierarchical framework, such that data from larger geographies can be used to support small area forecasts. Compared to the cohort-component model, the proposed method has lower data requirements, is suited to producing longer-term forecasts, and can output prediction intervals. Jannuzzi (2005) couples a regional-level cohort-component method with a system of differential equations, based on models of population dynamics used in ecology, to disaggregate population forecasts to municipalities.

\subsection{Small area microsimulation}

In contrast to most small area population forecasting methods, microsimulation models, by definition, operate at the scale of individuals rather than populations. Consequently, they require considerably more input data and data preparation than macro-scale models, but possess several 
beneficial features, including rich output detail across many population characteristics (van Imhoff \& Post, 1998). They also avoid the need for constraining between geographical scales because all output is aggregated from the individual scale. Two broad categories of spatial microsimulation model may be distinguished: dynamic models in which transitions between demographic states are modelled explicitly, and static models in which base period data are reweighted to aggregate constraints from macro-scale population estimates and projections (Ballas, Rossiter, et al. 2005; Tanton, 2014). Because they do not explicitly model demographic processes "static spatial microsimulation models are best for 'next day' analyses" based on whatif? policy scenarios (Tanton \& Edwards, 2013 p. 4). A pedagogical example of small area microsimulation is given in Lomax \& Smith (2017).

Examples of dynamic spatial microsimulation models can be found in Ballas, Rossiter, et al. (2005), Marois and Bélanger (2014, 2015), Wu and Birkin (2013), and Wu et al. (2011). We briefly describe two models here. Ballas, Clarke, et al. (2005) created SMILE (Simulation Model for the Irish Local Economy) to produce short-term population forecasts for small areas of Ireland for the periods 1991-1996 and 1996-2002. In the model, mortality probabilities are based on age, sex and location, while fertility probabilities are dependent on age, marital status and location. Probabilities of internal migration are obtained by randomly sampling from census data based on an individual's age, sex and county. International migration is excluded due to data limitations. The mean absolute percentage error for the total populations of small areas was $6.4 \%$ for the 1991-1996 projections. Marois and Bélanger (2014, 2015) describe the development and application of a microsimulation model for forecasting the populations of municipalities within the metropolitan region of Montreal, Canada. A key feature is the use of conditional logistic regression to allocate internal and international migrants to municipalities based on distance to the city centre, current municipality size, municipality development potential, population composition as well as geographic location. The model was applied to produce forecasts from 2011 to 2031. Validation over the 2006-11 period revealed a Mean Absolute Percentage Error (MAPE) of $3.4 \%$ for municipality total populations.

An example of a static spatial microsimulation model for small area population forecasting is described by Harding et al. (2011) and Vidyattama and Tanton (2010). The model SpatialMSM forecasts population and household characteristics for Statistical Local Areas (SLAs) of Australia (Harding et al. 2011). It takes independent macro-level forecasts of SLA populations by age and sex from 2007 to 2027, disaggregates them by labour force status, and then reweights the base period small area micro-level dataset to achieve consistency with the area/age/sex/labour force forecasts. 


\subsection{Machine learning}

Machine learning methods have proved very successful in a range of fields, such as speech recognition (Nassif et al., 2019), translation (Wu et al., 2016), computer vision (Voulodimos et al., 2018), bioinformatics (Li et al., 2019), and in games such as chess (Silver et al., 2018). However, some research suggests that these methods are often less accurate than traditional statistical methods for forecasting work. Makridakis et al. (2018) set out to evaluate the accuracy of forecasts produced by machine learning methods (including Long Short-Term Memory (LSTM) models, Bayesian Neural Networks, and Regression Trees) against traditional statistical methods (such as Exponential Smoothing, ARIMA, and an average of Simple Exponential Smoothing, Holt, and Damped exponential smoothing). They found that traditional methods were more accurate and had lower computational requirements than machine learning methods. The authors suggest that the reasons why many articles claim superior machine learning performance is that they do not include a comparison with a suitable benchmark method (particularly a traditional statistical model).

Riiman et al. (2019) evaluated an artificial neural network method known as the Long ShortTerm Memory (LSTM) model for forecasting the total population of Alabama counties at 10 year horizons, and compared them with forecasts from a cohort-component model, which produced a MAPE of $6.5 \%$ at 10 years. They produced machine learning forecasts using two data types (annual population estimates and decennial census populations) and two training regimes (training models on data from all counties and training a separate model for each county), giving four forecasts in total. When models were trained on one county at a time, they produced lower errors than when models were trained on data from all counties $(6.3 \%$ MAPE compared to $16.7 \%$ MAPE for annual population data, and $5.0 \%$ compared to $6.1 \%$ for decennial census populations). Thus, the LSTM model produced a significantly better forecast than the cohort-component model when a model was trained for each county and decennial data was used. The Alabama counties had relatively long time series available to train the models (decennial census data from 1910 to 2000, and mid-year population estimates from 1969 to 2000), a time series length not always available for small area populations.

Several papers have also applied machine learning methods to the demographic component inputs of small area population forecasts. Weber (2020) used several machine learning methods and data from 2005-2009 to predict net migration rates at the municipal level in Germany for 'education migration' (ages 18-24) and 'family migration' (ages 0-17 and 30-49) for the period 
2011-2015. The author reported forecasting performance by correlating observed and predicted values. Net migration rates for education migration achieved $R^{2}>0.5$ but $R^{2}=0.25$ was the best result for family migration. This suggests that machine learning methods with short time series could not adequately support forecasts of migration.

Several studies have applied such methods in forecasting related to the Shared Socioeconomic Pathways population scenarios. Chen et al. (2020) applied machine learning techniques to predict residential land use, and subsequently to forecast small grid square populations from 2015 to 2020, with forecasting constraints taken from the population scenarios. The methods used included two decision tree based ensemble methods, XGBoost (Georganos et al., 2018) and random forest (Belgiu et al., 2016), and a neural network algorithm as implemented in Hu et al. (2019). Striessnig et al. (2019) prepared county population forecasts by broad age group for the USA consistent with various Shared Socioeconomic Pathway scenarios for the period 2000 to 2100. Instead of relying on the cohort-component model, they used regression trees to forecast the share of a county's population in each broad age group based on past demographic characteristics. Census population data from 1980 to 2000 were used for model training. The age group shares were then applied to separate county population totals and constrained to national forecasts by age. Forecasts were compared against actual data during the 2000-2010 period, revealing an $\mathrm{R}^{2}$ of about 0.9 .

\subsection{Estimating and projecting small area component input data}

Another area of the small area population modelling literature focuses on estimating and forecasting the separate components of population change: fertility, mortality and migration. As is the case with small area estimation in general, one of the main challenges in obtaining estimates of components of population change at the local level is dealing with small or zero event counts, which make the underlying trends or patterns are unclear. Additionally, data on components may come from multiple sources, each having their own measurement issues and biases, that need to somehow be reconciled within the same estimation framework.

Because data in small areas is often sparse, many of the methods used for larger areas are unreliable. Scherbov and Ediev (2011) demonstrated the difficulty of creating robust life table statistics for small areas. They showed that traditional life table construction methods often give unacceptably high estimation bias and standard errors for population sizes below 5,000. Several approaches have been proposed to deal with this problem. Anson (2018) describes a multilevel model which uses national mortality rates to support the estimation of subnational mortality rates 
and applies it to 87 subnational units in Belgium to construct age-sex-specific mortality rates. Congdon (2014) produced county-level life expectancy estimates in the US based on a structured random effects model with a regression extension. This method allows for the consideration of various area characteristics, such as the ethnic mix, population density, and socio-economic indices, which enable stable life expectancy estimates to be formed with minimal amalgamation of counties. Dyrting (2020) and Gonzaga and Schmertmann (2016) both describe estimation of small area demographic rates based on TOPALS, a relational model developed by de Beer (2012) which can be used to smooth and project various age-specific demographic rates. It assumes that an age schedule can be represented as a combination of a standard age schedule and spline-smoothed ratios of local to standard rates. Gonzaga and Schmertmann (2016) developed a TOPALS-based method to estimate small area age-specific mortality rates for small areas with incomplete death registrations in Brazil. Dyrting (2020) extended this method using a penalizedsplines approach, where the smoothness of the fit is controlled with a single parameter, and then applied the method to estimate small area age-specific migration schedules in the Northern Territory, Australia (Dyrting, 2020). Simpson and Snowling (2017) evaluated three methods for preparing input data for small area cohort-component forecasts where input data was not available (or affordable). Methods evaluated included a No Local Variation approach which uses the same fertility, mortality, and migration inputs for all small areas within a wider region. The Local Calibration option constrains the No Local Variation assumptions by using total recorded births and deaths in each area, and estimates age-sex specific migration indirectly from two sets of population estimates. The Local Direct comparison projection uses small area fertility, mortality and migration age profiles of rates, directly estimated from available data. The authors conclude that the Local Calibration option gives the most plausible forecasts.

Whilst there are several approaches to support the estimation of population components in small areas, a large part of the recent literature has focused on developing Bayesian methods for estimation and forecasting. Bayesian methods have gained traction in demographic estimation since the United Nations Population Division began to utilize a Bayesian framework to produce its regular national and global population forecasts (Raftery et al., 2012). These methods have since been employed to estimate fertility, mortality, and migration at the global, regional, national and subnational levels (e.g., Alexander et al., 2017; Alkema \& New, 2014; Alkema et al., 2011; Assunção et al., 2005; Azose \& Raftery, 2015; Leknes \& Løkken, 2020; Schmertmann et al., 2013; Schmertmann \& Hauer, 2019). Bryant and Zhang (2018) describe a Bayesian statistical framework which uses multiple, often unreliable, data sources to estimate and forecast entire demographic systems, including births, deaths, internal migration and international migration) with age, sex, area and time details. 
In brief, Bayesian methods allow population processes to be conceptualised in a statistical framework which can combine both information from observed data and also prior beliefs about likely patterns in demographic processes. These methods are particularly suited to modelling demographic components, because they facilitate combining multiple data sources and dealing with missing data, and allow prior information on likely patterns across age and time to be incorporated. The use of statistical models allows patterns to be readily smoothed across time and information to be shared across space, and automatically accounts for and estimates uncertainty in forecasts.

Bayesian methods for small area demographic estimation first appeared in Peter Congdon's work on estimating local level life expectancies in the UK (Congdon, 2009). This approach of using Bayesian multilevel models has been extended by others studying mortality and other demographic processes. For example, Wakefield et al. (2019) use a spatio-temporal Bayesian model to estimate child mortality at the subnational model in data sparse contexts. Alexander et al. (2017) build on classical demographic model lifetable techniques to estimate small-area age specific mortality schedules. Jonker et al. (2012) show that a Bayesian Random Effects approach outperforms traditional life expectancy estimations. Traditional life expectancy estimations tend to generate unacceptably large biases and standard errors for populations of fewer than 5,000 person years, conversely the Bayesian approach allows estimates to be produced down to 2,000 person years (Jonker et al., 2012). Bryant and Zhang show how these types of methods can be employed to estimate small-area internal migration rates in both New Zealand and Iceland (Bryant \& Zhang, 2016; Zhang \& Bryant, 2020). A model providing a fuller demographic account for subnational regions of New Zealand is presented in Bryant and Graham (2013), where estimates are created using multiple data sources, including census and administrative data (e.g., tax system data, school enrollments, and electoral roll). In a different application of Bayesian methods, Schmertmann and Hauer (2019) develop methods to estimate fertility rates given population age structures. While not explicitly dealing with small populations, these methods are potentially useful in the small population context because often only population counts may be available.

\subsection{Forecast uncertainty}

Over the last three decades, the literature on quantifying population forecast uncertainty has grown considerably in scope and complexity. Methods have become increasingly sophisticated, probabilistic forecasts have been published for many case study countries, and several software 
packages made publicly available (Keilman, 2018, 2020). A few statistical agencies have now adopted probabilistic methods to prepare their official population forecasts (e.g., Statistics Netherlands, 2020; Statistics New Zealand, 2020; UN, 2019). Some researchers have focused on uncertainty for large subnational regions (e.g., Bertino et al., 2014; Rees \& Turton, 1998; Swanson \& Tayman, 2014; Wilson \& Bell, 2007; Wisniowski \& Raymer, 2016) but very little attention has been devoted to small area population forecasts, where errors tend to be highest and the need for quantifying uncertainty the greatest. It is not due to a lack of interest from users. In a recent survey, the majority of subnational population forecast users stated that they would like to receive information about population forecast uncertainty (Wilson \& Shalley, 2019). Among the methods which quantify uncertainty, Tayman (2011) makes a broad distinction between empirically-based prediction intervals based on analyses of historical forecast errors, and modelbased intervals generated by probabilistic and statistical models. Model-based intervals are quite data-hungry and complex to produce but provide an almost unlimited set of prediction intervals; empirically-based intervals provide less information but require less data and avoid complex model estimation.

Few papers describe probabilistic methods for quantifying local and small area forecast uncertainty. Bayesian methods for population forecasting estimate uncertainty as a natural byproduct of the estimation process (Bryant \& Zhang, 2018; Bryant \& Graham, 2013). Of the nonBayesian methods, one early contribution, due to Gullickson and Moen (2001), presented probabilistic population forecasts for one county in Minnesota and the rest of the State. A cohortcomponent model was run 1,000 times using fertility rates from a random walk with drift model, Lee-Carter mortality forecasts, and migration rates obtained by sampling randomly from recent net migration rates. Although relatively simple by today's standards, this was an innovative contribution at the time. A probabilistic cohort-component model was also created by Cameron and Poot (2011) to produce forecasts of district populations in the Waikato region of New Zealand. To keep the model relatively simple, they multiplied age-specific rates by factors drawn randomly from separate distributions for fertility, mortality, and net migration. These factors were maintained for all age-specific rates throughout the forecast horizon.

In contrast to this simulation approach, Rayer et al. (2009) created empirically-based prediction intervals. To do so, they prepared retrospective forecasts of total population for 2,482 counties in the US over many past decades using seven trend extrapolation methods. Final forecasts were created from a trimmed mean of the five remaining forecasts after excluding the highest and lowest for each area, and their errors were used to estimate $90^{\text {th }}$ percentile predictive intervals for use in later forecasts. The authors found that in most circumstances, the $90^{\text {th }}$ percentile error from 
one period proved quite accurate in predicting the $90 \%$ range of absolute percentage errors obtained in a subsequent period. This empirical approach is applied by the Bureau of Economic and Business Research at the University of Florida to create $75 \%$ prediction intervals for county population forecasts in Florida (Rayer \& Wang, 2020). The prediction intervals are allocated according to population size and recent growth rate.

Similarly, Wilson et al. (2018) created empirical prediction intervals for total population forecasts from an evaluation of 30 years' worth of local area population forecasts in Australia. $80^{\text {th }}$ percentile intervals were estimated from historical errors, smoothed across population size categories, and then applied to contemporary local area population forecasts based on jump-off year population sizes. Past error distributions were also used to estimate the 'shelf life' of a population forecast to indicate far into the future the forecast could be regarded as still 'suitable for consumption'. It was defined in this case as the number of years into the forecast horizon the $80 \%$ prediction interval would remain within $10 \%$ absolute percentage error. Up to $10 \%$ error was regarded as a reasonable quality forecast.

\subsection{Summary}

We briefly summarise the key contributions of the literature reviewed in the sub-sections above in Table 1 below.

Table 1: Key contributions in small area population forecasting methods, 2001-2020

\begin{tabular}{|c|c|c|}
\hline Section & Methods & Key contributions \\
\hline 3.1 & $\begin{array}{l}\text { Simple } \\
\text { extrapolative \& } \\
\text { comparative } \\
\text { methods }\end{array}$ & $\begin{array}{l}\text { - Several old and new extrapolative and comparative methods for } \\
\text { forecasting total small area populations work well, e.g., the } \\
\text { Linear/Exponential model (linear for +ve growth; exponential for -ve) } \\
\text { - Others perform poorly and/or are susceptible to generating impossible or } \\
\text { implausible forecasts, e.g., the constant growth rate difference model. } \\
\text { - Findings are not completely consistent between studies. }\end{array}$ \\
\hline 3.2 & $\begin{array}{l}\text { Hamilton-Perry } \\
\& \text { other } \\
\text { simplified } \\
\text { cohort- } \\
\text { component } \\
\text { methods }\end{array}$ & $\begin{array}{l}\text { - The Hamilton-Perry model generally produces respectable small area age- } \\
\text { sex population forecasts for relatively little input data. } \\
\text { - Forecasting accuracy improves by averaging forecasts with neighbouring } \\
\text { small areas, constraining to total population extrapolative forecasts, using } \\
\text { a mix of cohort change ratios (for declining populations) and cohort } \\
\text { change numbers (for growing populations), and modifying cohort change } \\
\text { ratios over time in line with those from a larger population. }\end{array}$ \\
\hline
\end{tabular}




\begin{tabular}{|c|c|c|}
\hline 3.3 & $\begin{array}{l}\text { Model } \\
\text { averaging \& } \\
\text { composite } \\
\text { models }\end{array}$ & $\begin{array}{l}\text { - Several studies show that averaged or composite models for small area } \\
\text { population forecasts generally achieve comparable or better forecast } \\
\text { accuracy than individual models. } \\
\text { - Cohort-component models constrained to extrapolative total population } \\
\text { forecasts tend to be yield more accurate small area forecasts than } \\
\text { unconstrained versions. }\end{array}$ \\
\hline 3.4 & $\begin{array}{l}\text { Models } \\
\text { incorporating } \\
\text { socio-economic } \\
\text { variables and } \\
\text { spatial } \\
\text { relationships }\end{array}$ & $\begin{array}{l}\text { - Regression models for forecasting small area total populations from a set } \\
\text { of independent variables generally do not produce substantially more } \\
\text { accurate forecasts than simple extrapolative models. } \\
\text { - Two studies which applied spatial weighting to forecast assumptions or } \\
\text { results were found to improve accuracy. }\end{array}$ \\
\hline 3.5 & $\begin{array}{l}\text { Models linking } \\
\text { population \& } \\
\text { housing }\end{array}$ & $\begin{array}{l}\text { - The data-efficient housing-unit model continues to be used for small area } \\
\text { population forecasts by researchers and practitioners. } \\
\text { - Recent work illustrates how it can be connected to the cohort-component } \\
\text { model and a headship rate household model (or similar) to provide } \\
\text { internally consistent population and household forecasts. } \\
\text { - Other approaches link population (or migration) age-sex profiles to } \\
\text { housing types, though this work has yet to be fully developed. }\end{array}$ \\
\hline 3.6 & $\begin{array}{l}\text { 'Downscaling' } \\
\text { models and } \\
\text { disaggregation } \\
\text { approaches }\end{array}$ & $\begin{array}{l}\text { - Many studies have applied various 'downscaling' approaches to } \\
\text { disaggregate national and large regional population forecasts to small } \\
\text { areas, particularly small grid squares. } \\
\text { - Methods vary from simple extrapolation to complex models which } \\
\text { estimate small area development potential. } \\
\text { - Many use assumptions which considerably simplify reality. } \\
\text { - Many models have not undergone forecast accuracy assessments. }\end{array}$ \\
\hline 3.7 & $\begin{array}{l}\text { Small area } \\
\text { microsimulation }\end{array}$ & $\begin{array}{l}\text { - Over the last decade a few small area dynamic microsimulation models } \\
\text { have been created. } \\
\text { - They provide rich output detail but at the cost of considerable input data } \\
\text { requirements. } \\
\text { - Short-term forecast accuracy has been reported as reasonable. }\end{array}$ \\
\hline 3.8 & $\begin{array}{l}\text { Machine } \\
\text { learning } \\
\text { methods }\end{array}$ & $\begin{array}{l}\text { - Machine learning methods are just beginning to be used in small area } \\
\text { demographic forecasting. } \\
\text { - The few examples to date present mixed results. Further evaluations are } \\
\text { required to determine the most appropriate machine learning methods for } \\
\text { small area forecasts and the circumstances in which they do better than } \\
\text { traditional methods. }\end{array}$ \\
\hline 3.9 & $\begin{array}{l}\text { Methods for } \\
\text { estimating and } \\
\text { projecting small } \\
\text { area component } \\
\text { input data }\end{array}$ & $\begin{array}{l}\text { - Several papers describe how robust small area component rate } \\
\text { assumptions can be prepared by borrowing information from elsewhere. } \\
\text { - Relational models, indirect estimation approaches, and several Bayesian } \\
\text { methods have been shown to provide good estimates. }\end{array}$ \\
\hline 3.10 & $\begin{array}{l}\text { Methods for } \\
\text { quantifying } \\
\text { small area } \\
\text { forecast } \\
\text { uncertainty }\end{array}$ & $\begin{array}{l}\text { - Only a few studies have created estimates of forecast uncertainty for small } \\
\text { area populations. } \\
\text { - Some are probabilistic in nature; others are empirically-based with } \\
\text { prediction intervals for total population based on past error distributions } \\
\text { (which have been shown to provide good estimates of forecast errors). }\end{array}$ \\
\hline
\end{tabular}

Source: authors' assessment 


\section{Research needs}

The review of small area population forecasting methods above documents many useful and novel contributions over the last two decades. But it also underlines the modest size of the literature on this topic, the many gaps and limitations, and the need for more research to enable the production of more accurate and informative small area population forecasts. Table 2 summarises what we consider to be the most important research needs in small area population forecasting.

Table 2: Some key research needs in small area population forecasting

\begin{tabular}{|l|l|}
\hline No. & Research needs \\
\hline 1 & $\begin{array}{l}\text { More complete, reliable, timely, and geographically consistent past demographic data for small } \\
\text { areas to provide a solid foundation for forecasts }\end{array}$ \\
\hline 2 & $\begin{array}{l}\text { More research on methods for estimating input fertility, mortality and migration rates for } \\
\text { forecasts, especially where there are modified/suppressed cell counts in published data }\end{array}$ \\
\hline 3 & $\begin{array}{l}\text { Comprehensive evaluation of forecast accuracy and plausibility of new methods when they are } \\
\text { proposed, preferably across many countries, and regular monitoring of previous forecasts }\end{array}$ \\
\hline 4 & $\begin{array}{l}\text { Publicly available dataset of small area population data on consistent boundaries for many } \\
\text { countries to enable researchers to test new methods in different demographic environments }\end{array}$ \\
\hline 5 & $\begin{array}{l}\text { Methods for forecasting the populations of small areas containing zero populations in part of } \\
\text { the base period, e.g., new greenfield housing areas }\end{array}$ \\
\hline 6 & $\begin{array}{l}\text { Methods for forecasting the changing age-sex structure of small area populations as they } \\
\text { undergo major change, e.g., re-development, densification, gentrification, long-run decline, } \\
\text { etc. }\end{array}$ \\
\hline 7 & Methods for dealing with major demographic shocks (e.g., COVID-19) in small area forecasts \\
\hline 8 & Research to improve forecast accuracy, including by combining and averaging models \\
\hline 9 & $\begin{array}{l}\text { Investigation of machine learning, spatial statistics, and other recent advances in quantitative } \\
\text { social science, and how they might be integrated with existing demographic methods }\end{array}$ \\
\hline 10 & $\begin{array}{l}\text { Research on the best ways of obtaining forecasts which are consistent between geographical } \\
\text { scales }\end{array}$ \\
\hline 11 & Investigation of the best ways to output consistent forecasts for multiple custom geographies \\
\hline 12 & Quantification of forecast uncertainty, and user-friendly approaches for communicating it \\
\hline 13 & $\begin{array}{l}\text { A better understanding of how forecasts are used in order to improve the usefulness of } \\
\text { forecasts and information provided to users }\end{array}$ \\
\hline 14 & User-friendly tools/packages/websites for practitioners and researchers \\
\hline 15 & $\begin{array}{l}\text { More researchers and forecasting research from countries other than the usual English- } \\
\text { speaking western countries, and more researchers from non-demography backgrounds to } \\
\text { cross-fertilise ideas. }\end{array}$ \\
\hline
\end{tabular}

Source: authors' assessment 
Small area population forecasts depend crucially on past demographic data being accurate, complete, and up-to-date. Unfortunately, this is often not the case. Accuracy tends to be lower for small areas than large subnational regions, some small area demographic data are unavailable (often the most important component, migration), and population estimates and components are regularly not published until 1-2 years after the reference date. Small area data also needs to be based on a consistent set of geographical boundaries, preferably the current set, so that recorded demographic change is real and not just an artefact of boundary change (Norman et al., 2003; Rees et al., 2004). Although past demographic data was outside the scope of our review, a prerequisite for improving small area population forecasting is to have accurate, complete and timely past and current small area demographic data. Much of this will require efforts from national statistical offices (perhaps including greater use of linked administrative datasets), but researchers can also contribute methods for geographical data conversion and more up-to-date estimation and nowcasting.

Where small area component data are available, a common challenge is dealing with sparse, noisy, and/or inaccurate data. For forecasting purposes, it is best to forecast smooth underlying rates, not noisy base period data. Our review notes several contributions to estimating and smoothing small area rates, particularly through the application of Bayesian methods. The next step is to refine methods and make user-friendly tools available. An additional challenge arises when available data is perturbed or suppressed in some manner by data providers for confidentiality reasons. More research is needed to devise strategies and methods to recover or estimate data where this issue exists.

It would also be helpful if historical validation routinely occurred when new forecasting methods are proposed. A key question to ask is: if a forecasting method was applied $n$ years ago, how well would it have forecast the population for the most recent year we have a population estimate for? And would it have done better than existing methods? While many studies address these questions, some of the forecasting methods covered in the review did not undergo any validation, or were subject to only a very limited evaluation. This was particularly the case for some of the downscaling methods and microsimulation models. Evaluations of new methods can reveal important information about their forecast characteristics, typical forecast accuracy, and whether they improve on existing methods. In addition to historical validation, there has been limited evaluation of 'real' small area population forecasts produced by statistical offices and researchers. This too can reveal important findings about methods that work well, and those that do not. It would be helpful if all such evaluations used a consistent set of error measures to 
enable comparisons to be made easily between different studies. Ideally, demographers would agree on a recommended standard set of error measures to be applied in all forecast evaluations.

The historical validation of methods would be made much easier if there were publicly available small area demographic datasets. Ideally, the datasets would include population estimates for many commonly used spatial units (e.g., census tracts, wards, SA2 areas) and many countries so that that forecasting methods could be evaluated in a variety of demographic environments. Ideally, the datasets would span several decades of population data on a consistent set of geographical boundaries, and include not just population estimates but also the demographic components of change. Data for several countries might shed light on why different extrapolative and comparative small area forecasting methods proved most accurate in different countries (section 3.1). Small area demographic data covering a useful period of time is currently quite difficult to obtain ${ }^{2}$. We therefore wish to invite researchers and statistical offices to share small area population estimates (where permitted), and accompanying component data time series if available, to be uploaded to the github page at https://demographic-datasets-network.github.io/.

Most small area forecasting methods require some base period data, either to extrapolate past population numbers into the future, or to estimate recent fertility, mortality and migration rates or patterns. But sometimes a small area starts the forecast horizon with a population of zero and no demographic history. This is the case for small areas on a city fringe where construction will begin on a new housing estate in the near future. The housing-unit model could be used to forecast total population numbers, but any age-sex detail will need to be provided by additional data or another model, such as the cohort-component model (along with fertility, mortality and migration assumptions). The literature currently provides little guidance on how such forecasts are best prepared (especially migration rate age profiles), so further research to enable good quality forecasts to be produced for these types of areas would be helpful.

Similarly, many current methods are poorly suited to forecasting the populations of small areas undergoing major changes which are likely to re-shape the area's population size and age structure, such as major housing redevelopment projects or the construction of large-scale institutional accommodation. In addition, many existing modelling approaches cannot easily incorporate major shocks to demographic trends, such as those caused by COVID-19 or the closure of the local area's main employer. Methods which are able to handle these sorts of changes would likely improve the quality and plausibility of small area population forecasts. A

\footnotetext{
2 though large datasets containing grid square population counts do exist, such as the Gridded Population of the World at https://sedac.ciesin.columbia.edu/ and the WorldPop project at https://www.worldpop.org/.
} 
related challenge is how to deal with those small area populations, often in rural and remote regions, experiencing sustained long-term decline. Should their populations be forecast to decline for many decades ahead, possibly reaching zero at some point? It would be useful to develop methods which forecast a plausible minimum population size based on theory and past experience.

Forecast accuracy is one of the key concerns of demographers creating new forecasting methods, and our review documents numerous efforts to improve forecast accuracy using a variety of methods. While this is challenging at the small area scale, several studies show that averaging or combining models often lowers forecast errors. Further research along these lines to investigate model combinations not yet tested would seem sensible. In addition, further exploration of machine learning methods, spatial statistics, and Bayesian methods, which are growing in popularity in the social sciences, would be valuable to determine whether forecast accuracy could be improved further. But it is important not to 'throw the baby out with the bathwater'. Our view is that these newer methods are best combined with proven existing demographic models, to draw on the strength of both new and established methods.

One of the themes absent in the literature review is how best to produce forecasts which are consistent between geographical scales (Rees, 1994). Small area population forecasts are often produced as part of a wider set of forecasts at multiple geographical scales (e.g., small area, State/province, and national). A common approach is to apply top-down constraining to the projected subnational demographic components of change in which components for each area are scaled by the same factor. Where components are not projected, an alternative is to adjust population growth using the plus-minus technique for example (Smith et al. 2013). But sometimes considerable amounts of constraining are required, effectively revising assumptions by a substantial margin. An alternative is to apply a bottom-up method in which higher geography forecasts are simply the sum of smaller area forecasts. Although a few methods for ensuring forecast consistency exist (e.g., van Imhoff \& Keilman, 1991; H. Li \& Hyndman, 2021), research is needed to find optimal, and ideally simple, ways of creating assumptions and forecasts which are consistent between geographical scales.

Another geography-related challenge is to investigate the best ways to output consistent forecasts for multiple custom geographies. While geographical conversion is relatively straightforward for historical data using various spatial interpolation methods (Comber \& Zeng, 2019), the equivalent for forecasts is more complex because population growth is unlikely to be uniform across a small area and ancillary data for interpolation is required for future years. In addition, 
the geographical conversion of internal migration projections is far from simple because some inter-area flows become intra-area flows, and vice versa. One approach would be to create forecasts for ultra-small areas which can be aggregated on a best-fit basis to most custom geographies, but forecasting ultra-small area populations presents a huge challenge.

Also requiring further research is the quantification of forecast uncertainty (Tayman, 2011). Estimates of uncertainty are provided for a few sets of small area forecasts, as the review shows, but mostly uncertainty is not considered. Where measures of uncertainty are provided, they are generally empirically-based intervals for total populations only. Much remains to be done to provide users with comprehensive estimates of uncertainty for small population by age and sex and for projected components. A challenge exists in adapting probabilistic methods to cope with the more limited data environment for small areas, and to prevent the forecasting process from becoming very complex and time-consuming. Also needed are user-friendly methods of communicating uncertainty to non-technical users of forecasts (Wilson, 2018).

We hope at least some of the above suggestions for further research are realised in coming years, but it is just as important to translate new research into practical tools. Doing so hugely increases the value of the research. Recent years have seen the creation of many useful demography tools and software packages for practitioners and researchers, some of which are available via the very useful Applied Demography Toolbox website at https://applieddemogtoolbox.github.io/. The development of additional user-friendly small area population forecasting tools and packages, based on new research, would be most helpful.

Another issue which has received little attention is understanding how forecasts are used (Diamond et al, 1990). If demographers know how forecasts are interpreted and used in planning and decision-making, then it should be possible for information about the forecasts, including their strengths and limitations, to be tailored to key user groups. And it might result in greater attention being given to particular aspects of the forecasts when preparing input data and assumptions, and validating outputs. Research on understanding more about how small area population forecasts are used and interpreted could lead to improvements which enhance their value to users.

Finally, it would be a positive development if more subnational population forecasting research was undertaken in countries other than the usual English-speaking Western countries, and by researchers from those countries. It is certainly the case that our review is dominated by research from North America, the UK and Australia. It might also be beneficial if small area population 
forecasting research involved more researchers from non-demography backgrounds to crossfertilise ideas from other disciplines. 


\section{Conclusions}

In this paper we have reviewed the literature on small area population forecasting from the last two decades, and suggested several areas suitable for further research. The scope of our review was fairly tightly defined in terms of small area size, forecasting methods, and publication dates, so we did not include related topics such as derived forecasts, quality assurance, and small area population estimation. Even within the narrow scope of the review, there are inevitably some papers we have missed. However, the limited scope of the review enabled us to cover small area forecasting methods in some detail, and we hope this is of use to researchers and practitioners.

A key conclusion from this review is that there is a discrepancy between the importance of small area population forecasting for planning purposes on the one hand, and the state of the small area forecasting methods toolbox on the other. Small area population forecasts are widely used for planning purposes and influence many substantial investment decisions. Although many important methodological contributions have been made over the last 20 years, research funding and progress lags behind that for national level, and large subnational level, population forecasting. We hope that further research, particularly along the lines of the suggestions made in Table 2, will lead to the development of better forecasting methods, and therefore more accurate and useful small area population forecasts, in the future. 


\section{Declarations}

\section{Funding}

This research was funded by the Australian Government through the through the Australian Research Council's Discovery Projects funding scheme (project DP200101480).

\section{Conflicts of interest}

None declared.

\section{Availability of data and material}

Not applicable

\section{Code availability}

Not applicable

\section{Ethics approval}

Ethics approval for this project was granted by the Melbourne School of Population and Global Health (MSPGH) Human Ethics Advisory Group (HEAG), Reference Number: 2020-2057513335-2.

\section{Acknowledgements}

We are grateful to authors of papers included in our review for reading over our brief summaries of their papers in the annotated bibliography and making corrections where necessary. Jack Baker and Eddie Hunsinger kindly provided helpful comments on an earlier draft of the paper. All errors and omissions, however, remain the authors' responsibility. 


\section{References}

Alexander, M., Zagheni, E., \& Barbieri, M. (2017). A Flexible Bayesian Model for Estimating Subnational Mortality. Demography, 54(6), 2025-2041. https://doi.org/10.1007/s13524017-0618-7

Alho, J. M. (2015). Population Forecasts. In J. D. Wright (Ed.), International Encyclopedia of the Social \& Behavioral Sciences (Second Edition) (pp. 593-596). Oxford: Elsevier.

Alkema, L., \& New, J. R. (2014). Global estimation of child mortality using a Bayesian B-spline bias-reduction model. The Annals of Applied Statistics, 8(4), 2122-2149. https://doi.org/10.1214/14-AOAS768

Alkema, L., Raftery, A. E., Gerland, P., Clark, S. J., Pelletier, F., Buettner, T., \& Heilig, G. K. (2011). Probabilistic projections of the total fertility rate for all countries. Demography, 48(3), 815-839. https://doi.org/10.1007/s13524-011-0040-5

Alonso González, M. L., Fernández Vázquez, E., \& Rubiera Morollón, F. (2015). A methodological note for local demographic projections: A shift-share analysis to disaggregate official aggregated estimations. Revista Electrónica de Comunicaciones y Trabajos de Asepuma, 16(1), 43-50.

Anson, J. (2018). Estimating local mortality tables for small areas: An application using Belgian sub-arrondissements. Quetelet Journal, 6(1), 73-97. https://doi.org/10.14428/rqj2018.06.01.04

Assunção, R. M., Schmertmann, C. P., Potter, J. E., \& Cavenaghi, S. M. (2005). Empirical Bayes estimation of demographic schedules for small areas. Demography, 42(3), 537-558. https://doi.org/doi.org/10.1353/dem.2005.0022

Athukorala, W., Neelawela, P., Wilson, C., Miller, E., Sahama, T., Grace, P., Hefferan, M., Dissanayake, P., \& Manawadu, O. (2010). Forecasting Population Changes and Service Requirements in the Regions: A Study of Two Regional Councils in Queensland, Australia. Economic Analysis and Policy, 40(3), 327-349. https://doi.org/10.1016/S03135926(10)50033-X

Azose, J. J., \& Raftery, A. E. (2015). Bayesian Probabilistic Projection of International Migration. Demography, 52(5), 1627-1650. https://doi.org/10.1007/s13524-015-0415-0

Baker, J., Alcántara, A., Ruan, X., Watkins, K., \& Vasan, S. (2014). Spatial weighting improves accuracy in small-area demographic forecasts of urban census tract populations. Journal of Population Research, 31(4), 345-359. https://doi.org/10.1007/s12546-014-9137-1

Baker, J., Ruan, X., Alcantara, A., Jones, T., Watkins, K., McDaniel, M., Frey, M., Crouse, N., Rajbhandari, R., Morehouse, J., Sanchez, J., Inglis, M., Baros, S., Penman, S., Morrison, S., Budge, T., \& Stallcup, W. (2008). Density-dependence in urban housing unit growth: 
An evaluation of the Pearl-Reed model for predicting housing unit stock at the census tract level. Journal of Economic and Social Measurement, 33(2-3), 155-163. https://doi.org/10.3233/JEM-2008-0301

Baker, J., Swanson, D. A., Tayman, J., \& Tedrow, L. M. (2017). Cohort Change Ratios and their Applications. Springer International Publishing.

Baker, J., Swanson, D., \& Tayman, J. (2020). The Accuracy of Hamilton-Perry Population Projections for Census Tracts in the United States. Population Research and Policy Review, 1-14. https://doi.org/10.1007/s11113-020-09601-y

Ballas, D., Clarke, G. P., \& Wiemers, E. (2005). Building a dynamic spatial microsimulation model for Ireland. Population, Space and Place, 11(3), 157-172. https://doi.org/10.1002/psp.359

Ballas, D., Rossiter, D., Thomas, B., Clarke, G., \& Dorling, D. (2005). Geography Matters: Simulating the Local Impacts of National Social Policies. Joseph Rowntree Foundation.

Bates, J. M., \& Granger, C. W. (1969). The combination of forecasts. Journal of the Operational Research Society, 20(4), 451-468. https://doi.org/10.1057/jors.1969.103

Belgiu, M., Drăguţ, L. J. (2016). Random forest in remote sensing: A review of applications and future directions. ISPRS Journal of Photogrammetry and Remote Sensing, 114, 24-31. https://doi.org/10.1016/j.isprsjprs.2016.01.011

Bell, M. (1997). Small Area Forecasting for Infrastructure Planning: Towards a Better Practice. Department of Industry, Science and Tourism, Canberra.

Bertino, S., Casacchia, O., \& Crisci, M. (2014). Stochastic population projections: an application to the Rome Metropolitan Area. In M. Marsili \& G. Capacci (Eds.) Proceedings of the 6th Eurostat/UNECE Work Session on Demographic Projections (pp. 216-229). National Institute of Statistics, Rome, Italy.

Boke-Olén, N., Abdi, A. M., Hall, O., \& Lehsten, V. (2017). High-resolution African population projections from radiative forcing and socio-economic models, 2000 to 2100. Scientific Data, 4(1), 1-9. https://doi.org/10.1038/sdata.2016.130

Booth, H. (2006). Demographic forecasting: 1980 to 2005 in review. International Journal of Forecasting, 22(3), 547-581. https://doi.org/10.1016/j.ijforecast.2006.04.001

Breidenbach, P., Kaeding, M., \& Schaffner, S. (2019). Population projection for Germany 20152050 on grid level (RWI-GEO-GRID-POP-Forecast). Jahrbücher für Nationalökonomie und Statistik, 239(4), 733-745. https://doi.org/10.1515/jbnst-2017-0149

Bryan, T. (2004). Chapter 20 Population estimates. In J. S. Siegel \& D. A. Swanson (Eds.), The Methods and Materials of Demography (2 ed., pp. 523-560): Elsevier Academic Press. 
Bryant, J., \& Zhang, J. L. (2016). Bayesian forecasting of demographic rates for small areas: emigration rates by age, sex, and region in New Zealand, 2014-2038. Statistica Sinica 26, 1337-1363. https://doi.org/10.5705/ss.2014.200t

Bryant, J., \& Zhang, J.L. (2018). Bayesian Demographic Estimation and Forecasting (1st ed.). CRC Press. https://doi.org/10.1201/9780429452987

Bryant, J., R. , \& Graham, P., J. (2013). Bayesian Demographic Accounts: Subnational Population Estimation Using Multiple Data Sources. Bayesian Analysis, 8(3), 591-622. https://doi.org/10.1214/13-BA820

Cameron, M. P., \& Cochrane, W. (2017). Using land-use modelling to statistically downscale population projections to small areas. Australasian Journal of Regional Studies, 23(2), 195.

Cameron, M. P., \& Poot, J. (2011). Lessons from stochastic small-area population projections: The case of Waikato subregions in New Zealand. Journal of Population Research, 28(23), 245-265. https://doi.org/10.1007/s12546-011-9056-3

Chen, Y., Li, X., Huang, K., Luo, M., \& Gao, M. (2020). High-Resolution Gridded Population Projections for China Under the Shared Socioeconomic Pathways. Earth's Future, 8(6), e2020EF001491. https://doi.org/10.1029/2020EF001491

Chi, G. (2009). Can knowledge improve population forecasts at subcounty levels? Demography, 46(2), 405-427. https://doi.org/10.1353/dem.0.0059

Chi, G., \& Voss, P. R. (2011). Small-area population forecasting: Borrowing strength across space and time. Population, Space and Place, 17(5), 505-520. https://doi.org/10.1002/psp.617

Chi, G., \& Wang, D. (2017). Small-area population forecasting: a geographically weighted regression approach. In D. A. Swanson (Ed.), The Frontiers of Applied Demography (pp. 449-471). Springer. https://doi.org/10.1007/978-3-319-43329-5_21

Chi, G., \& Zhu, J. (2008). Spatial Regression Models for Demographic Analysis. Population Research and Policy Review, 27(1), 17-42. https://doi.org/10.1007/s11113-007-9051-8

Chi, G., Zhou, X., \& Voss, P. R. (2011). Small-area population forecasting in an urban setting: a spatial regression approach. Journal of Population Research, 28(2-3), 185-201. https://doi.org/10.1007/s12546-011-9053-6

Clemen, R. T. (1989). Combining forecasts: A review and annotated bibliography. International Journal of Forecasting, 5(4), 559-583. https://doi.org/10.1016/0169-2070(89)90012-5

Comber, A., \& Zeng, W. (2019). Spatial interpolation using areal features: A review of methods and opportunities using new forms of data with coded illustrations. Geography Compass 13(10), e12465. https://doi.org/10.1111/gec3.12465 
Congdon, P. (2009). Life expectancies for small areas: A Bayesian random effects methodology. International Statistical Review, 77(2), 222-240. https://doi.org/10.1111/j.17515823.2009.00080.x

Congdon, P. (2014). Estimating life expectancies for US small areas: a regression framework. Journal of Geographical Systems, 16(1), 1-18. https://doi.org/10.1007/s10109-013-01774

de Beer, J. (2012). Smoothing and projecting age-specific probabilities of death by TOPALS. Demographic Research, 27(20), 543-592. https://doi.org/10.4054/DemRes.2012.27.20

Diamond, I., Tesfaghiorghis, H., \& Joshi, H. (1990). The uses and users of population projections in Australia. Journal of the Australian Population Association, 7(2), 151-170. https://doi.org/10.1007/BF03029362

Dittgen, A., \& Dutreuilh, C. (2005). Housing and household size in local population dynamics. Population (English Edition, 2002-), 60(3), 259-298. https://doi.org/10.2307/4148195

Dockery, A. M., Harris, M. N., Holyoak, N., \& Singh, R. B. (2020). A methodology for projecting sparse populations and its application to remote Indigenous communities. Journal of Geographical Systems, 1-25. https://doi.org/10.1007/s10109-020-00329-z

Dyrting, S. (2020). Smoothing migration intensities with P-TOPALS. Demographic Research, 43, 1527-1570. https://doi.org/10.4054/DemRes.2020.43.55

Feng, Q., Wang, Z., Choi, S., \& Zeng, Y. (2020). Forecast Households at the County Level: An Application of the ProFamy Extended Cohort-Component Method in Six Counties of Southern California, 2010 to 2040. Population Research and Policy Review, 39(2), 253281. https://doi.org/10.1007/s11113-019-09531-4

Foss, W. (2002). Small area population forecasting. The Appraisal Journal, 70(2), 163-172. Franzén, M., \& Karlsson, T. (2010). Using national data to obtain small area estimators for population projections on sub-national level. Paper presented at the Conference of European Statisticians, Lisbon, Portugal. https://www.unece.org/fileadmin/DAM/stats/documents/ece/ces/ge.11/2010/sp.2.e.pdf

Georganos, S., Grippa, T., Vanhuysse, S., Lennert, M., Shimoni, M., Kalogirou, S., \& Wolff, E. (2018). Less is more: optimizing classification performance through feature selection in a very-high-resolution remote sensing object-based urban application. GIScience \& Remote Sensing, 55(2), 221-242. https://doi.org/10.1080/15481603.2017.1408892

GLA. (2018). Projected Demand for School Places. London: Greater London Authority. Retrieved from https://data.london.gov.uk/dataset/pan-london-school-place-demand Gonzaga, M. R., \& Schmertmann, C. P. (2016). Estimating age-and sex-specific mortality rates for small areas with TOPALS regression: an application to Brazil in 2010. Revista 
Brasileira de Estudos de População, 33(3), 629-652. https://doi.org/10.20947/S0102$30982016 \mathrm{c} 0009$

Goodwin, P. (2009). New evidence on the value of combining forecasts. Foresight: The International Journal of Applied Forecasting(12), 33-35.

Grip, R. S., \& Grip, M. L. (2020). Using Multiple Methods to Provide Prediction Bands of K-12 Enrollment Projections. Population Research and Policy Review, 39(1), 1-22. https://doi.org/10.1007/s11113-019-09533-2

Gu, H., Lao, X., \& Shen, T. (2020). Research Progress on Spatial Demography. In X. Ye \& H. Lin (Eds.), Spatial Synthesis: Computational Social Science and Humanities (pp. 125145). Springer International Publishing.

Gullickson, A., \& Moen, J. (2001). The use of stochastic methods in local area population forecasts. Paper prepared for the annual meeting of the Population Association of America, Washington DC.

Hachadoorian, L., Gaffin, S. R., \& Engelman, R. (2011). Projecting a gridded population of the world using ratio methods of trend extrapolation. In R. P. Cincotta, \& L. J. Gorenflo (Eds.) Human Population: Its Influences on Biological Diversity (pp. 13-25). SpringerVerlag Berlin Heidelberg.

Hamilton, C. H., \& Perry, J. (1962). A short method for projecting population by age from one decennial census to another. Social Forces, 41(2), 163-170. https://doi.org/10.2307/2573607

Hansen, H.S. (2010). Small-Area Population Projections - A Key Element in Knowledge Based e-Governance. In K.N. Andersen, E. Francesconi, A. Grönlund, \& T.M. van Engers (Eds.), EGOVIS 2010. Lecture Notes in Computer Science: Vol. 6267. Electronic Government and the Information Systems Perspective (pp. 32-46). Springer, Berlin, Heidelberg. https://doi.org/10.1007/978-3-642-15172-9_4

Harding, A., Vidyattama, Y., \& Tanton, R. (2011). Demographic change and the needs-based planning of government services: Projecting small area populations using spatial microsimulation. Journal of Population Research, 28(2-3), 203-224. https://doi.org/10.1007/s12546-011-9061-6

Harzing, A. (2007). Publish or perish software [Computer software]. Retrieved from https://harzing.com/resources/publish-or-perish

Hauer, M. E. (2017) Migration induced by sea-level rise could reshape the US population landscape. Nature Climate Change, 7, 321-325. https://doi.org/10.1038/nclimate3271

Hauer, M. E. (2019). Population projections for US counties by age, sex, and race controlled to shared socioeconomic pathway. Scientific Data, 6(1), 1-15. https://doi.org/10.1038/sdata.2019.5 
Hauer, M. E., Evans, J. M., \& Alexander, C. R. (2015). Sea-level rise and sub-county population projections in coastal Georgia. Population and Environment, 37(1), 44-62. https://doi.org/10.1007/s11111-015-0233-8

Hauer, M. E., Evans, J. M., \& Mishra, D. R. (2016). Millions projected to be at risk from sealevel rise in the continental United States. Nature Climate Change, 6, 691-695. https://doi.org/10.1038/nclimate2961

Hu, L., He, S., Han, Z., Xiao, H., Su, S., Weng, M., \& Cai, Z. (2019). Monitoring housing rental prices based on social media: An integrated approach of machine-learning algorithms and hedonic modeling to inform equitable housing policies. Land Use Policy, 82, 657-673. https://doi.org/10.1016/j.landusepol.2018.12.030

Inoue, T. (2017). A new method for estimating small area demographics and its application to long-term population projection. In D. A. Swanson (Ed.), The Frontiers of Applied Demography (pp. 473-489). Springer. https://doi.org/10.1007/978-3-319-43329-5_22

Isserman, A. M. (1977). The accuracy of population projections for subcounty areas. Journal of the american Institute of Planners, 43(3), 247-259. https://doi.org/10.1080/01944367708977786

Jiang, B., Jin, H., Liu, N., Quirk, M., and Searle, B. (2007). A HMM-based hierarchical framework for long-term population projection of small areas. In M. A. Orgun and J. Thornton (Eds.), AI 2007: Advances in Artificial Intelligence. AI 2007. Lecture Notes in Computer Science, vol 4830 (pp. 694-698). Springer. https://doi.org/10.1007/978-3-54076928-6_77

Jonker, M. F., van Lenthe, F. J., Congdon, P. D., Donkers, B., Burdorf, A., \& Mackenbach, J. P. (2012). Comparison of Bayesian Random-Effects and Traditional Life Expectancy Estimations in Small-Area Applications. American Journal of Epidemiology, 176(10), 929-937. https://doi.org/10.1093/aje/kws152

Kanaroglou, P. S., Maoh, H. F., Newbold, B., Scott, D. M., \& Paez, A. (2009). A demographic model for small area population projections: an application to the Census Metropolitan Area of Hamilton in Ontario, Canada. Environment and Planning A: Economy and Space, 41(4). 964-979. https://doi.org/10.1068/a40172

Keilman, N. (2018). Probabilistic demographic forecasts. Vienna Yearbook of Population Research, 16, 25-36. https://doi.org/10.1553/populationyearbook2018s025

Keilman, N. (2020). Uncertainty in Population Forecasts for the Twenty-First Century. Annual Review of Resource Economics, 12(1), 449-470. https://doi.org/10.1146/annurevresource-110319-114841

Leknes, S., \& Løkken, S. A. (2020). Empirical Bayes estimation of local demographic rates. An application using Norwegian registry data. Statistics Norway. 
https://www.ssb.no/en/befolkning/artikler-og-publikasjoner/empirical-bayes-estimationof-local-demographic-rates

Li, H., \& Hyndman, R. J. (2021). Assessing mortality inequality in the U.S.: What can be said about the future? Insurance: Mathematics and Economics, 99, 152-162. https://doi.org/https://doi.org/10.1016/j.insmatheco.2021.03.014

Li, N., \& Lee, R. (2005). Coherent mortality forecasts for a group of populations: An extension of the Lee-Carter method. Demography, 42(3), 575-594. https://doi.org/10.1353/dem.2005.0021

Li, T., \& Corcoran, J. (2011). Testing dasymetric techniques to spatially disaggregate the regional population forecasts for South East Queensland. Journal of Spatial Science, 56(2), 203-221. https://doi.org/10.1080/14498596.2011.623343

Li, Y., Huang, C., Ding, L., Li, Z., Pan, Y., \& Gao, X. (2019). Deep learning in bioinformatics: Introduction, application, and perspective in the big data era. Methods, 166, 4-21. https://doi.org/10.1016/j.ymeth.2019.04.008

Lomax, N., \& Smith, A. (2017). Microsimulation for demography. Australian Population Studies, 1(1), 73-85. https://doi.org/10.37970/aps.v1i1.14

Makridakis, S., Spiliotis, E., \& Assimakopoulos, V. (2018). Statistical and Machine Learning forecasting methods: Concerns and ways forward. PloS One, 13(3), e0194889. https://doi.org/10.1371/journal.pone.0194889

Marois, G., \& Bélanger, A. (2014). Microsimulation Model Projecting Small Area Populations Using Contextual Variables: An Application to the Montreal Metropolitan Area, 20062031. International Journal of Microsimulation, 7(1), 158-193. https://doi.org/10.34196/ijm.00097

Marois, G., \& Bélanger, A. (2015). Analyzing the impact of urban planning on population distribution in the Montreal metropolitan area using a small-area microsimulation projection model. Population and Environment, 37(2), 131-156. https://doi.org/10.1007/s11111-015-0234-7

Marshall, A., \& Simpson, L. (2009). Population sustainability in rural communities: The case of two British national parks. Applied Spatial Analysis and Policy, 2(2), 107-127. https://doi.org/10.1007/s12061-008-9017-1

Matthews, S. A., \& Parker, D. M. (2013). Progress in spatial demography. Demographic Research, 28, 271. https://doi.org/10.4054/DemRes.2013.28.10

Mazzuco, S., \& Keilman, N. (Eds.) (2020). Developments in Demographic Forecasting: Springer, Cham.

McKee, J. J., Rose, A. N., Bright, E. A., Huynh, T., \& Bhaduri, B. L. (2015). Locally adaptive, spatially explicit projection of US population for 2030 and 2050. Proceedings of the 
National Academy of Sciences, 112(5), 1344-1349.

https://doi.org/10.1073/pnas.1405713112

Merkens, J. L., Reimann, L., Hinkel, J., \& Vafeidis, A. T. (2016). Gridded population projections for the coastal zone under the Shared Socioeconomic Pathways. Global and Planetary Change, 145, 57-66. https://doi.org/10.1016/j.gloplacha.2016.08.009

Myers, D. (1990). Housing demography: Linking demographic structure and housing markets: University of Wisconsin Press.

Nassif, A. B., Shahin, I., Attili, I., Azzeh, M., \& Shaalan, K. (2019). Speech recognition using deep neural networks: A systematic review. IEEE access, 7, 19143-19165. https://doi.org/10.1109/ACCESS.2019.2896880

Nawaz, R., Rees, P., Clark, S., Mitchell, G., McDonald, A., Kalamandeen, M. Lambert, C., \& Henderson, R. (2019). Long-term projections of domestic water demand: a case study of London and the Thames Valley. Journal of Water Resource Planning \& Management, 2019, 145(11): 05019017. DOI: 10.1061/(ASCE)WR.1943-5452.0001088

Norman, P., Rees, P., \& Boyle, P. (2003). Achieving data compatibility over space and time: creating consistent geographical zones. International Journal of Population Geography 9(5), 365-386. https://doi.org/10.1002/ijpg.294

O’Neill, B., Kriegler, E., Riahi, K., Ebi, K., Hallegatte, S., Carter, T., Mathur, R., van Vuuren, D. (2014). A new scenario framework for climate change research: the concept of shared socioeconomic pathways. Climate Change 122, 387-400.

Openshaw, S., \& Van Der Knaap, G. (1983). Small area population forecasting: some experience with British models. Tijdschrift voor economische en sociale geografie, 74(4), 291-304. https://doi.org/10.1111/j.1467-9663.1983.tb00976.x

Pearl, R., \& Reed, L. J. (1920). On the rate of growth of the population of the United States since 1790 and its mathematical representation. Proceedings of the National Academy of Sciences of the United States of America, 6(6), 275. https://doi.org/10.1073/pnas.6.6.275

Portland State University Population Research Center. (2015). Methods and Data for Developing Coordinated Population Forecasts. Retrieved from https://pdxscholar.library.pdx.edu/prc_pub/32/

Pritchett, H. S. (1891). A formula for predicting the population of the United States. Publications of the American Statistical Association, 2(14), 278-286. https://doi.org/10.1080/15225437.1891.10504009

QGSO. (2018). Queensland Government population projections, 2018 edition: Methodology and assumptions. Queensland: Queensland Treasury Retrieved from https://www.qgso.qld.gov.au/issues/2676/qld-government-population-projectionsmethodology-assumptions-2018-edn.pdf 
Raftery, A. E., Li, N., Ševčíková, H., Gerland, P., \& Heilig, G. K. (2012). Bayesian probabilistic population projections for all countries. Proceedings of the National Academy of Sciences, 109(35), 13915-13921. https://doi.org/10.1073/pnas.1211452109

Rayer, S. (2008). Population Forecast Errors: A Primer for Planners. Journal of Planning Education and Research, 27(4), 417-430. https://doi.org/10.1177/0739456x07313925

Rayer, S. (2015). Demographic Techniques: Small-area estimates and projections. In J. D Wright (Ed.), International Encyclopedia of the Social \& Behavioral Sciences ( $2^{\text {nd }}$ ed., pp. 162169). Elsevier. https://doi.org/10.1016/B978-0-08-097086-8.31015-7

Rayer, S., \& Smith, S. K. (2010). Factors affecting the accuracy of subcounty population forecasts. Journal of Planning Education and Research, 30(2), 147-161. https://doi.org/10.1177/0739456X10380056

Rayer, S., \& Wang, Y. (2020). Projections of Florida Population by County, 2020-2045, with Estimates for 2019. Bureau of Economic and Business Research, 53(186), 1 - 9.

Rayer, S., Smith, S. K., \& Tayman, J. (2009). Empirical prediction intervals for county population forecasts. Population Research and Policy Review, 28(6), 773. https://doi.org/10.1007/s11113-009-9128-7

Raymer, J., Bonaguidi, A., \& Valentini, A. (2006). Describing and projecting the age and spatial structures of interregional migration in Italy. Population, Space and Place, 12(5), 371388. https://doi.org/10.1002/psp.414

Rees, P. (1994). Key issues in subnational projection models. University of Leeds, School of Geography.

Rees, P., \& Turton, I. (1998). Geocomputation: solving geographical problems with new computing power. Environment and Planning A, 30, 1835-1838.

Rees, P., Clark, S., Wohland, P., \& Kalamandeen, M. (2019). Evaluation of Sub-National Population Projections: a Case Study for London and the Thames Valley. Applied Spatial Analysis and Policy, 12(4), 797-829. https://doi.org/10.1007/s12061-018-9270-x

Rees, P., Norman, P., \& Brown, D. (2004). A framework for progressively improving small area population estimates. Journal of the Royal Statistical Society: Series A (Statistics in Society), 167(1), 5-36. https://doi.org/10.1111/j.1467-985X.2004.00289.x

Rees, P., Wohland, R., Norman, P., \& Lomax, N. (2015). Sub-national projection methods for Scotland and Scottish areas: A review and recommendations. In A Consultancy for National Records of Scotland, Edinburgh.

Reinhold, M., \& Thomsen, S. L. (2015). Subnational population projections by age: An evaluation of combined forecast techniques. Population Research and Policy Review, 34(4), 593-613. https://doi.org/10.1007/s11113-015-9362-0 
Riiman, V., Wilson, A., Milewicz, R., \& Pirkelbauer, P. (2019). Comparing Artificial Neural Network and Cohort-Component Models for Population Forecasts. Population Review, 58(2), 100-116. https://doi.org/10.1353/prv.2019.0008

Scherbov, S., \& Ediev, D. (2011). Significance of life table estimates for small populations: Simulation-based study of standard errors. Demographic Research, 24(22), 527-550. https://doi.org/10.4054/DemRes.2011.24.22

Schmertmann, C. P., \& Hauer, M. E. (2019). Bayesian estimation of total fertility from a population's age-sex structure. Statistical Modelling, 19(3), 225-247. https://doi.org/10.1177/1471082X18801450

Schmertmann, C. P., Cavenaghi, S. M., Assunção, R. M., \& Potter, J. E. (2013). Bayes plus Brass: estimating total fertility for many small areas from sparse census data. Population Studies, 67(3), 255-273. https://doi.org/10.1080/00324728.2013.795602

Schmitt, R. C., \& Crosetti, A. H. (1951). Accuracy of the ratio method for forecasting city population. Land Economics, 27(4), 346-348. https://doi.org/10.2307/3159671

Shang, H. L., \& Booth, H. (2020). Synergy in fertility forecasting: improving forecast accuracy through model averaging. Genus, 76(1), 1-23. https://doi.org/10.1186/s41118-020-00099$\mathrm{y}$

Silver, D., Hubert, T., Schrittwieser, J., Antonoglou, I., Lai, M., Guez, A., . . Hassabis, D. (2018). A general reinforcement learning algorithm that masters chess, shogi, and Go through self-play. Science, 362(6419), 1140-1144. https://doi.org/10.1126/science.aar6404

Simpson, L. (2002). Geography conversion tables: a framework for conversion of data between geographical units. International Journal of Population Geography, 8(1), 69-82. https://doi.org/10.1002/ijpg.235

Simpson, L. (2017). Integrated local demographic forecasts constrained by the supply of housing or jobs: Practice in the UK. In Swanson, D. A. (ed.) The Frontiers of Applied Demography (pp. 329-350): Springer.

Simpson, L., \& Snowling, H. (2011). Estimation of local demographic variation in a flexible framework for population projections. Journal of Population Research, 28(2-3), 109-127. https://doi.org/10.1007/s12546-011-9060-7

Smith, S. K. (1987). Tests of forecast accuracy and bias for county population projections. Journal of the American Statistical Association, 82(400), 991-1003. https://doi.org/10.1080/01621459.1987.10478528

Smith, S. K., \& Shahidullah, M. (1995). An evaluation of population projection errors for census tracts. Journal of the American Statistical Association, 90(429), 64-71. https://doi.org/10.1080/01621459.1995.10476489 
Smith, S. K., Tayman, J., \& Swanson, D. A. (2013). A Practitioner's Guide to State and Local Population Projections. Springer.

Statistics Netherlands. (2020). Forecast: Population growth unabated in the next 50 years. Retrieved from https://www.cbs.nl/en-gb/news/2020/51/forecast-population-growthunabated-in-the-next-50-years

Statistics New Zealand. (2020). National population projections: 2020(base)-2073. Retrieved from https://www.stats.govt.nz/information-releases/national-population-projections2020base2073

Stimson, R., Bell, M., Corcoran, J., \& Pullar, D. (2012). Using a large scale urban model to test planning scenarios in the Brisbane-South East Queensland region. Regional Science Policy \& Practice, 4(4), 373-392. https://doi.org/10.1111/j.1757-7802.2012.01082.x

Striessnig, E., Gao, J., O’Neill, B. C., \& Jiang, L. (2019). Empirically based spatial projections of US population age structure consistent with the shared socioeconomic pathways. Environmental Research Letters, 14(11), 114038. https://doi.org/10.1088/17489326/ab4a3a

Swanson, D. A., \& Tayman, J. (2012). Housing Unit Method. In Subnational Population Estimates (pp. 137-163). Springer.

Swanson, D. A., \& Tayman, J. (2014). Measuring uncertainty in population forecasts: a new approach. In M. Marsili \& G. Capacci (Eds.) Proceedings of the 6th Eurostat/UNECE Work Session on Demographic Projections (pp. 203-215). National Institute of Statistics, Rome, Italy.

Swanson, D. A., Schlottmann, A., \& Schmidt, B. (2010). Forecasting the population of census tracts by age and sex: An example of the Hamilton-Perry method in action. Population Research and Policy Review, 29(1), 47-63. https://doi.org/10.1007/s11113-009-9144-7

Tanton, R. (2014). A review of spatial microsimulation methods. International Journal of Microsimulation, 7(1), 4-25.

Tanton, R., \& Edwards, K. (2013). Spatial Microsimulation: A Reference Guide for Users (Vol. 6): Springer Science \& Business Media.

Tayman, J. (2011). Assessing uncertainty in small area forecasts: State of the practice and implementation strategy. Population Research and Policy Review, 30(5), 781-800. https://doi.org/10.1007/s11113-011-9210-9

Tayman, J., \& Swanson, D. A. (2017). Using modified cohort change and child-woman ratios in the Hamilton-Perry forecasting method. Journal of Population Research, 34(3), 209-231. https://doi.org/10.1007/s12546-017-9190-7 
Tayman, J., Smith, S. K., \& Lin, J. (2007). Precision, bias, and uncertainty for state population forecasts: An exploratory analysis of time series models. Population Research and Policy Review, 26(3), 347-369. https://doi.org/10.1007/s11113-007-9034-9

Tobler, W. R. (1970). A computer movie simulating urban growth in the Detroit region. Economic Geography, 46(sup1), 234-240. https://doi.org/10.2307/143141

UN. (2019). World Population Prospects 2019. New York: United Nations.

Van Imhoff, E., \& Keilman, N. (1991). LIPRO 2.0: an application of a dynamic demographic projection model to household structure in the Netherlands. Amsterdam: Swets \& Zeitlinger.

https://www.uio.no/studier/emner/sv/oekonomi/ECON1730/h10/undervisningsmateriale/ nidicbgs-publ-23.pdf

van Imhoff, E., \& Post, W. (1998). Microsimulation Methods for Population Projection. Population: An English Selection, 10(1), 97-138.

Vasan, S., Baker, J., \& Alcántara, A. (2018). Use of Kernel Density and Raster Manipulation in GIS to Predict Population in New Mexico Census Tracts. Review of Economics Finance, 14, 25-38.

Vidyattama, Y., \& Tanton, R. (2010). Projecting Small Area Statistics with Australian Microsimulation Model (SPATIALMSM). Australasian Journal of Regional Studies, 16(1), 99-126.

Voss, P. R. (2007). Demography as a Spatial Social Science. Population Research and Policy Review, 26(5), 457-476. https://doi.org/10.1007/s11113-007-9047-4

Voulodimos, A., Doulamis, N., Doulamis, A., \& Protopapadakis, E. (2018). Deep learning for computer vision: A brief review. Computational intelligence and neuroscience, 2018. https://doi.org/10.1155/2018/7068349

Wakefield, J., Fuglstad, G.-A., Riebler, A., Godwin, J., Wilson, K., \& Clark, S. J. (2019). Estimating under-five mortality in space and time in a developing world context. Statistical Methods in Medical Research, 28(9), 2614-2634. https://doi.org/10.1177/0962280218767988

Walters, A., \& Cai, Q. (2008). Investigating the use of holt-winters time series model for forecasting population at the state and sub-state levels. Paper prepared for the Population Association of America 2008 Annual Meeting Program, New Orleans, LA. https://paa2008.princeton.edu/papers/80184

Weber, H. (2020). How Well Can the Migration Component of Regional Population Change be Predicted? A Machine Learning Approach Applied to German Municipalities. Comparative Population Studies, 45. https://doi.org/10.12765/CPoS-2020-08 
White, H. R. (1954). Empirical study of the accuracy of selected methods of projecting state populations. Journal of the American Statistical Association, 49(267), 480-498. https://doi.org/10.1080/01621459.1954.10483516

Wilson, T. (2011). A review of sub-regional population projection methods. Queensland Centre for Population Research, The University of Queensland.

Wilson, T. (2014). Simplifying Local Area Population and Household Projections with POPART. In M. N. Hoque \& L. B. Potter (Eds.), Emerging Techniques in Applied Demography (pp. 25-38). Springer Netherlands. http://dx.doi.org/10.1007/978-94-0178990-5_3

Wilson, T. (2015). New evaluations of simple models for small area population forecasts. Population, Space and Place, 21(4), 335-353. https://doi.org/10.1002/psp.1847

Wilson, T. (2016). Evaluation of alternative cohort-component models for local area population forecasts. Population Research Policy Review, 35(2), 241-261. https://doi.org/10.1007/s11113-015-9380-y

Wilson, T. (2017a). A checklist for reviewing draft population projections. Charles Darwin University. https://researchers.cdu.edu.au/en/publications/a-checklist-for-reviewing-draftpopulation-projections

Wilson, T. (2017b). Does averaging yield more accurate local and regional population forecasts? Applied Spatial Analysis and Policy, 10(4), 497-513. https://doi.org/10.1007/s12061-0169194-2

Wilson, T. (2018). Communicating population forecast uncertainty using perishable food terminology. Research Briefs, (RB03/2018), 1-15. http://www.cdu.edu.au/sites/default/files/research-brief-2018-03_0.pdf

Wilson, T., \& Bell, M. (2007). Probabilistic regional population forecasts: The example of Queensland, Australia. Geographical Analysis, 39(1), 1-25. https://doi.org/10.1111/j.1538-4632.2006.00693.x

Wilson, T., \& Rees, P. (2005). Recent developments in population projection methodology: A review. Population, Space and Place, 11(5), 337-360. https://doi.org/10.1002/psp.389

Wilson, T., \& Rowe, F. (2011). The forecast accuracy of local government area population projections: a case study of Queensland. The Australasian Journal of Regional Studies, 17(2), 204-243

Wilson, T., \& Shalley, F. (2019). Subnational population forecasts: Do users want to know about uncertainty? Demographic Research, 41, 367-392. https://doi.org/10.4054/DemRes.2019.41.13 
Wilson, T., Brokensha, H., Rowe, F., \& Simpson, L. (2018). Insights from the evaluation of past local area population forecasts. Population Research Policy Review, 37(1), 137-155. https://doi.org/10.1007/s11113-017-9450-4

Wisniowski, A., \& Raymer, J. (2016). Bayesian multiregional population forecasting: England. Joint Eurostat/UNECE Work Session on Demographic Projections, Geneva, 18-20.

Wu, B. M., Birkin, M. H., \& Rees, P. H. (2011). A Dynamic MSM With Agent Elements for Spatial Demographic Forecasting. Social Science Computer Review, 29(1), 145-160. https://doi.org/10.1177/0894439310370113

Wu, B., \& Birkin, M. (2013). Moses: A Dynamic Spatial Microsimulation Model for Demographic Planning. In R. Tanton \& K. Edwards (Eds.), Spatial Microsimulation: A Reference Guide for Users (pp. 171-193). Springer Netherlands.

Wu, Y., Schuster, M., Chen, Z., Le, Q., Macherey, W., Krikun, M.,Cao, Y., Gao, Q., Macherey, K., Klingner, J., Shah, A., Johnson, M., Liu, X., Kaiser, Ł., Gouws, S., Kato, Y., Kudo, T., Kazawa, H., Stevens, K., . . . Dean, J. (2016). Google's Neural Machine Translation System: Bridging the Gap between Human and Machine Translation. arXiv preprint, https://arxiv.org/abs/1609.08144.

Xanthos, G., Ladias, C. A., \& Genitsaropoulos, C. (2013). A method for forecasting population changes in alpine, semi-alpine and lowland communities of Epirus region in Greece. Regional Science Inquiry Journal, 1, 173-179.

Zhang, J. L., \& Bryant, J. (2020). Bayesian disaggregated forecasts: internal migration in Iceland. In S. Mazzuco, \& N. Keilman (Eds.), Developments in Demographic Forecasting (pp. 193-215). Springer. https://doi.org/10.1007/978-3-030-42472-5_10

Zoraghein, H., \& O’Neill, B. C. (2020b). US State-level Projections of the Spatial Distribution of Population Consistent with Shared Socioeconomic Pathways. Sustainability, 12(8), 3374. https://doi.org/10.3390/su12083374

Zoraghein, H., \& O'Neill, B. C. (2020a). A spatial population downscaling model for integrated human-environment analysis in the United States. Demographic Research, 43, 15631606. https://doi.org/10.4054/DemRes.2020.43.54 


\section{Supplementary Information}

Table A: Annotated bibliography of papers on small area population forecasting methods

\begin{tabular}{|c|c|}
\hline Reference and URL & Key points \\
\hline $\begin{array}{l}\text { Alexander, M., Zagheni, E., \& } \\
\text { Barbieri, M. (2017). A Flexible } \\
\text { Bayesian Model for Estimating } \\
\text { Subnational Mortality. Demography, } \\
\text { 54(6), 2025-2041. } \\
\text { https://doi.org/10.1007/s13524-017- } \\
0618-7\end{array}$ & $\begin{array}{l}\text { A Bayesian modelling framework is presented to estimate } \\
\text { age-specific mortality rates at the subnational level. The } \\
\text { model incorporates principal components derived from } \\
\text { model mortality schedules into a time series framework, } \\
\text { allowing for pooling of information across space and time. }\end{array}$ \\
\hline $\begin{array}{l}\text { Alonso González, M. L., Fernández } \\
\text { Vázquez, E., \& Rubiera Morollón, F. } \\
\text { (2015). A methodological note for } \\
\text { local demographic projections: A shift- } \\
\text { share analysis to disaggregate official } \\
\text { aggregated estimations. Revista } \\
\text { Electrónica de Comunicaciones y } \\
\text { Trabajos de Asepuma, 16(1), 43-50. } \\
\text { http://www.revistarecta.com/n16.html }\end{array}$ & $\begin{array}{l}\text { An adapted shift-share method to disaggregate regional } \\
\text { age-sex-specific population forecasts to local areas is } \\
\text { proposed. Local area projected population growth is a } \\
\text { function of regional total population growth (regional } \\
\text { effect), regional change by age group (age effect), and local } \\
\text { area age-specific growth (local effect). The method is } \\
\text { relatively simple, has modest data requirements, and } \\
\text { ensures local forecasts sum to the regional projection. } \\
\text { Example forecasts for small areas within the Asturias } \\
\text { region of Spain are presented. }\end{array}$ \\
\hline $\begin{array}{l}\text { Anson, J. (2018). Estimating local } \\
\text { mortality tables for small areas: An } \\
\text { application using Belgian sub- } \\
\text { arrondissements. Revue } \\
\text { Quetelet/Quetelet Journal, 6(1), 73-97. } \\
\text { https://doi.org/10.14428/rqj2018.06.01. } \\
\underline{\text { O4 }}\end{array}$ & $\begin{array}{l}\text { A multilevel model for subnational mortality rates is } \\
\text { described, estimated on the basis of national rates and local } \\
\text { overall mortality (Standardised Mortality Ratios) and social } \\
\text { conditions (household structure, education, urban/rural, and } \\
\text { region). The estimation method is applied to } 87 \text { areas of } \\
\text { Belgium to construct age- and sex-specific mortality rates. } \\
\text { The authors find that these rates can be reliably estimated } \\
\text { on the basis of local social conditions thus enabling valid } \\
\text { life tables to be estimated for small area populations. }\end{array}$ \\
\hline $\begin{array}{l}\text { Assunção, R. M., Schmertmann, C. P., } \\
\text { Potter, J. E., \& Cavenaghi, S. M. } \\
\text { (2005). Empirical Bayes estimation of } \\
\text { demographic schedules for small areas. } \\
\text { Demography, 42(3), 537-558. } \\
\text { https://doi.org/doi.org/10.1353/dem.20 } \\
05.0022\end{array}$ & $\begin{array}{l}\text { Age-specific fertility rates are estimated for small areas in } \\
\text { Brazil. The authors devise an Empirical Bayes approach } \\
\text { which borrows information from nearby areas more than } \\
\text { distant areas and from age-specific rates which are strongly } \\
\text { correlated across areas. Almost all fertility age schedules } \\
\text { are found to be plausible and sensible. }\end{array}$ \\
\hline
\end{tabular}




\begin{tabular}{|c|c|}
\hline Reference and URL & Key points \\
\hline $\begin{array}{l}\text { Athukorala, W., Neelawela, P., Wilson, } \\
\text { C., Miller, E., Sahama, T., Grace, P., } \\
\text { Hefferan, M., Dissanayake, P., \& } \\
\text { Manawadu, O. (2010). Forecasting } \\
\text { Population Changes and Service } \\
\text { Requirements in the Regions: A Study } \\
\text { of Two Regional Councils in } \\
\text { Queensland, Australia. Economic } \\
\text { Analysis and Policy, 40(3), 327-349. } \\
\text { https://doi.org/10.1016/S0313- } \\
5926(10) 50033-X\end{array}$ & $\begin{array}{l}\text { ARIMA models are applied to forecast the total populations } \\
\text { of two council areas in Queensland, Australia. Population } \\
\text { data over a base period of } 1946 \text { to } 2009 \text { is used to forecast } \\
\text { out to } 2025 . \text { Also presented are } 95 \% \text { prediction intervals } \\
\text { (which appear to be very narrow). Then forecasts are } \\
\text { prepared for sub-regions of each council "by using the } \\
\text { average population share of each sub-region". The authors } \\
\text { describe their approach as "verifiable, transparent, and easy } \\
\text { to comprehend" and view it as "more theoretically sound } \\
\text { than the cohort-component method of population } \\
\text { forecasting". }\end{array}$ \\
\hline $\begin{array}{l}\text { Baker, J., Ruan, X., Alcantara, A., } \\
\text { Jones, T., Watkins, K., McDaniel, M., } \\
\text { Frey, M., Crouse, N., Rajbhandari, R., } \\
\text { Morehouse, J., Sanchez, J., Inglis, M., } \\
\text { Baros, S., Penman, S., Morrison, S., } \\
\text { Budge, T., \& Stallcup, W. (2008). } \\
\text { Density-dependence in urban housing } \\
\text { unit growth: An evaluation of the } \\
\text { Pearl-Reed model for predicting } \\
\text { housing unit stock at the census tract } \\
\text { level. Journal of Economic and Social } \\
\text { Measurement, 33(2-3), 155-163. } \\
\text { https://doi.org/10.3233/JEM-2008- } \\
\text { 0301 }\end{array}$ & $\begin{array}{l}\text { The authors are interested in the housing-unit model to } \\
\text { forecast small area populations, and in this paper they focus } \\
\text { on the dwelling component of the model. They apply the } \\
\text { Pearl-Reed logistic curve to forecast dwelling growth in } \\
\text { urban census tracts in Bernalillo County, New Mexico, } \\
\text { USA. The base period covers } 1990-2000 \text { and forecasts are } \\
\text { made out to 2007. It is concluded that "overall, the Pearl- } \\
\text { Reed model performed remarkably well in predicting } \\
\text { housing unit stocks at the census tract level in this study." }\end{array}$ \\
\hline $\begin{array}{l}\text { Baker, J., Alcantara, A., Ruan, X., } \\
\text { Watkins, K., \& Vasan, S. (2013) A } \\
\text { comparative evaluation of error and } \\
\text { bias in census tract-level age/sex- } \\
\text { specific population estimates: } \\
\text { Component I (Net-Migration) vs } \\
\text { Component III (Hamilton-Perry). } \\
\text { Population Research and Policy } \\
\text { Review 32(6), 919-942. } \\
\text { https://doi.org/10.1007/s11113-013- } \\
\text { 9295-4 }\end{array}$ & $\begin{array}{l}\text { Although labelled as population 'estimates', the authors } \\
\text { effectively created small area age-sex population forecasts } \\
\text { using two methods. They were: the Component I method } \\
\text { (cohort-component with net migration) and the Component } \\
\text { III method (Hamilton-Perry). Forecasts for census tracts in } \\
\text { selected New Mexico counties were produced for } 2010 \\
\text { from a } 2000 \text { jump-off date with constraining to total } 2010 \\
\text { county population estimates. Over the } 10 \text { year forecast } \\
\text { horizon, MedAPEs for census tract total populations were } \\
28.4 \% \text { for Component I and } 26.1 \% \text { for Component III. }\end{array}$ \\
\hline
\end{tabular}




\begin{tabular}{|c|c|}
\hline Reference and URL & Key points \\
\hline $\begin{array}{l}\text { Baker, J., Alcántara, A., Ruan, X., } \\
\text { Watkins, K., \& Vasan, S. (2014). } \\
\text { Spatial weighting improves accuracy in } \\
\text { small-area demographic forecasts of } \\
\text { urban census tract populations. Journal } \\
\text { of Population Research, 31(4), 345- } \\
\text { 359. } \\
\text { https://doi.org/10.1007/s12546-014- } \\
137-1\end{array}$ & $\begin{array}{l}\text { The process for creating population forecasts by age and } \\
\text { sex for } 221 \text { urban census tracts in New Mexico, USA, is } \\
\text { described. The forecasts were created by a Hamilton-Perry } \\
\text { shortcut cohort model, which gave the first set of } \\
\text { projections, and then two types of spatial weighting were } \\
\text { applied to the initial forecasts to create two more sets. The } \\
\text { spatial weighting involved averaging initial projections for } \\
\text { each census tract with those of its neighbours - as defined } \\
\text { by rook and queen contiguity matrices. Forecasts were } \\
\text { prepared for } 2000-2010 \text { and then evaluated against } 2010 \\
\text { Census data. The spatially-weighted forecasts proved more } \\
\text { accurate than those from the regular Hamilton-Perry model } \\
\text { across most age groups. }\end{array}$ \\
\hline $\begin{array}{l}\text { Baker, J., Swanson, D., \& Tayman, J. } \\
\text { (2020). The Accuracy of Hamilton- } \\
\text { Perry Population Projections for } \\
\text { Census Tracts in the United States. } \\
\text { Population Research and Policy } \\
\text { Review, 1-14. } \\
\text { https://doi.org/10.1007/s11113-020- } \\
\text { 09601-y }\end{array}$ & $\begin{array}{l}\text { The paper reports an evaluation of the Hamilton-Perry } \\
\text { model applied to about } 65,000 \text { census tracts across the } \\
\text { USA. A base period of } 1990-2000 \text { is used to estimate } \\
\text { cohort change ratios and forecasts are produced out to } 2010 \text {. } \\
5 \text { year age groups and intervals are used, with 0-4 and 5-9 } \\
\text { populations forecast using child/adult ratios from the jump- } \\
\text { off year. Two sets of forecasts are produced: (i) } \\
\text { uncontrolled and (ii) controlled to total populations forecast } \\
\text { using linear extrapolation. The authors find that controlling } \\
\text { the forecasts "creates noticeable reductions in the MAPEs } \\
\text { in every age group for both males and females". }\end{array}$ \\
\hline $\begin{array}{l}\text { Ballas, D., Clarke, G. P., \& Wiemers, } \\
\text { E. (2005). Building a dynamic spatial } \\
\text { microsimulation model for Ireland. } \\
\text { Population, Space and Place, 11(3), } \\
\text { 157-172. } \\
\text { https://doi.org/10.1002/psp.359 }\end{array}$ & $\begin{array}{l}\text { The authors describe the development of SMILE, a } \\
\text { dynamic small area microsimulation projection model for } \\
\text { Ireland. It is based on a geography of small area District } \\
\text { Electoral Divisions. Input data includes simulated small } \\
\text { area base period microdata, containing socio-economic } \\
\text { attributes for individuals in each small area, as well as } \\
\text { assumptions about fertility, mortality and internal } \\
\text { migration. The model was run to produce forecasts for } 1996 \\
\text { and } 2002 \text {. }\end{array}$ \\
\hline $\begin{array}{l}\text { Boke-Olén, N., Abdi, A. M., Hall, O., } \\
\& \text { Lehsten, V. (2017). High-resolution } \\
\text { African population projections from } \\
\text { radiative forcing and socio-economic } \\
\text { models, } 2000 \text { to } 2100 . \text { Scientific data, } \\
4(1), 1-9 . \\
\text { https://doi.org/10.1038/sdata.2016.130 }\end{array}$ & $\begin{array}{l}\text { The authors describe the creation of a high-resolution } \\
\text { annual gridded population forecasts for the whole of Africa } \\
\text { for every year from } 2000 \text { to } 2100 \text {. They used a geography } \\
\text { of } 30 \text { arc second grid squares (about } 1 \mathrm{~km}^{2} \text { at the equator). } \\
\text { Forecasts were created by disaggregating country-level } \\
\text { population projections from the Shared Socioeconomic } \\
\text { Pathways database at the International Institute for Applied } \\
\text { Systems Analysis (IIASA) in combination with land use } \\
\text { projections that follow the representative concentration } \\
\text { pathways. The disaggregation process used data on roads, } \\
\text { water bodies, country borders, and distance to urban } \\
\text { centres. }\end{array}$ \\
\hline
\end{tabular}




\begin{tabular}{|c|c|}
\hline Reference and URL & Key points \\
\hline $\begin{array}{l}\text { Breidenbach, P., Kaeding, M., \& } \\
\text { Schaffner, S. (2019). Population } \\
\text { projection for Germany 2015-2050 on } \\
\text { grid level (RWI-GEO-GRID-POP- } \\
\text { Forecast). Jahrbücher für } \\
\text { Nationalökonomie und Statistik, } \\
\text { 239(4), 733-745. } \\
\underline{\text { https://doi.org/10.1515/jbnst-2017- }} \\
\underline{0149}\end{array}$ & $\begin{array}{l}\text { The paper reports how population forecasts by age and sex } \\
\text { for } 1 \mathrm{~km}^{2} \text { grid squares were prepared for Germany for the } \\
\text { period } 2015 \text { to } 2050 \text {. A cohort-component model with net } \\
\text { migration numbers was used and applied to each grid } \\
\text { square. Mortality rates were derived from a Lee-Carter } \\
\text { model fitted at the national scale with national mortality } \\
\text { rates used for each small area. Net international migration } \\
\text { was distributed to grid squares according to the population } \\
\text { distribution and has a fixed age structure. Net internal } \\
\text { migration was set to zero. Fertility was assumed to rise a } \\
\text { little in the future. County-specific age-specific fertility } \\
\text { rates were applied to grid squares, with spatial fertility } \\
\text { differentials maintained over time. }\end{array}$ \\
\hline $\begin{array}{l}\text { Bryant, J., \& Zhang, J. L. (2016). } \\
\text { Bayesian forecasting of demographic } \\
\text { rates for small areas: emigration rates } \\
\text { by age, sex, and region in New } \\
\text { Zealand, 2014-2038. 1337-1363. } \\
\text { https://doi.org/10.5705/ss.2014.200t }\end{array}$ & $\begin{array}{l}\text { The authors develop a Bayesian hierarchical model to } \\
\text { estimate and forecast emigration rates by region in New } \\
\text { Zealand. The model deals with small sample sizes by taking } \\
\text { advantage of regularities in migration rates by age, sex, } \\
\text { time and region. The authors also develop an approach to } \\
\text { deal with missing data and changing geographic } \\
\text { boundaries. }\end{array}$ \\
\hline $\begin{array}{l}\text { Bryant, J., R. , \& Graham, P., J. } \\
\text { (2013). Bayesian Demographic } \\
\text { Accounts: Subnational Population } \\
\text { Estimation Using Multiple Data } \\
\text { Sources. Bayesian Analysis, 8(3), 591- } \\
\text { 622. } \\
\text { https://doi.org/10.1214/13-BA820 }\end{array}$ & $\begin{array}{l}\text { The authors provide a Bayesian framework which supports } \\
\text { the disaggregated estimation of the components of } \\
\text { population change, with detail on region, sex, age, and time. } \\
\text { They apply this approach to subnational regions of New } \\
\text { Zealand, with consideration to seven components of } \\
\text { population change: births, deaths, internal in and out } \\
\text { migration and external in- and out- migration. Multiple data } \\
\text { sources were used to develop their model, including both } \\
\text { census and administrative data (e.g. tax system data, school } \\
\text { enrolments, electoral roll). Estimates and forecasts for a } \\
\text { subset of model outputs are presented. }\end{array}$ \\
\hline $\begin{array}{l}\text { Cameron, M. P., \& Cochrane, W. } \\
\text { (2017). Using land-use modelling to } \\
\text { statistically downscale population } \\
\text { projections to small areas. Australasian } \\
\text { Journal of Regional Studies, 23(2), } \\
\text { 195. } \\
\text { https://www.anzrsai.org/assets/Uploads } \\
\text { /PublicationChapter/AJRS-23.2-pages- } \\
\text { 195-to-216.pdf }\end{array}$ & $\begin{array}{l}\text { The paper explains how population forecasts for area units } \\
\text { (populations generally between } 1,500 \text { and } 3,000 \text { ) were } \\
\text { prepared for the Waikato region of New Zealand. Forecasts } \\
\text { for larger regions (territorial authorities) created by cohort- } \\
\text { component models were distributed to area units via the } \\
\text { Waikato Integrated Scenario Explorer (WISE), a detailed } \\
\text { land-use projection model. Several regression models were } \\
\text { fitted to distribute non-residential population, with } \\
\text { residential populations based on the land use change model. } \\
\text { A short-term out-of-sample test forecast compared forecasts } \\
\text { with those of two simple models, finding the authors' } \\
\text { forecasts were competitive with one of the simple models } \\
\text { and had only marginally higher errors than the other. }\end{array}$ \\
\hline
\end{tabular}




\begin{tabular}{|c|c|}
\hline Reference and URL & Key points \\
\hline $\begin{array}{l}\text { Cameron, M. P., \& Poot, J. (2011). } \\
\text { Lessons from stochastic small-area } \\
\text { population projections: The case of } \\
\text { Waikato subregions in New Zealand. } \\
\text { Journal of Population Research, 28(2- } \\
\text { 3), } 245 \text { - 265. } \\
\text { https://doi.org/10.1007/s12546-011- } \\
\text { 9056-3 }\end{array}$ & $\begin{array}{l}\text { The authors present a stochastic cohort-component model } \\
\text { for subnational areas and apply it to produce forecasts for } \\
\text { districts within the Waikato region of New Zealand. The } \\
\text { cohort-component model combines internal and } \\
\text { international migration in the form of age-specific net } \\
\text { migration rates. Stochastic forecasts are created by taking } \\
\text { deterministic age-specific rates and multiplying them by } \\
\text { probabilistic factors drawn randomly from separate } \\
\text { distributions for fertility, mortality, and net migration. The } \\
\text { factors apply to all age-specific rates for each component } \\
\text { for the whole forecast horizon. }\end{array}$ \\
\hline $\begin{array}{l}\text { Chen, Y., Li, X., Huang, K., Luo, M., } \\
\& \text { Gao, M. (2020). High-Resolution } \\
\text { Gridded Population Projections for } \\
\text { China Under the Shared } \\
\text { Socioeconomic Pathways. Earth's } \\
\text { Future, 8(6), e2020EF001491. } \\
\text { https://doi.org/10.1029/2020EF001491 }\end{array}$ & $\begin{array}{l}\text { The paper describes the preparation of small } 100 \mathrm{~m}^{2} \text { grid } \\
\text { square population forecasts for China for the period } 2015 \text { to } \\
\text { 2050. The authors used machine learning (XGBoost, } \\
\text { random forest, and neural network algorithms) to predict } \\
\text { residential land use change and therefore population. The } \\
\text { forecasts are constrained to the Intergovernmental Panel on } \\
\text { Climate Change's shared socioeconomic pathways (SSPs) } \\
\text { population scenarios. }\end{array}$ \\
\hline $\begin{array}{l}\text { Chi, G. (2009). Can knowledge } \\
\text { improve population forecasts at } \\
\text { subcounty levels? Demography, } 46(2) \text {, } \\
\text { 405-427. } \\
\text { https://doi.org/10.1353/dem.0.0059 }\end{array}$ & $\begin{array}{l}\text { A regression approach to forecasting the total populations } \\
\text { of subcounty areas is described. Four regression models } \\
\text { were applied to forecast the populations of Minor Civil } \\
\text { Divisions in Wisconsin. The dependent variable was the } \\
\text { population growth rate and the explanatory variables } \\
\text { included demographic and socioeconomic characteristics, } \\
\text { transport accessibility, natural amenities, and land } \\
\text { development characteristics. The base period was } 1980-90 \\
\text { with forecasts produced out to 2000. Comparisons with } 4 \\
\text { simple linear and exponential extrapolative models reveal } \\
\text { the regression approach does not outperform extrapolation. } \\
\text { The performance of the regression methods is discounted at } \\
\text { subcounty levels by temporal instability and the scale } \\
\text { effect. }\end{array}$ \\
\hline $\begin{array}{l}\text { Chi, G., \& Voss, P. R. (2011). Small- } \\
\text { area population forecasting: Borrowing } \\
\text { strength across space and time. } \\
\text { Population, Space and Place, 17(5), } \\
\text { 505-520. } \\
\text { https://doi.org/10.1002/psp.617 }\end{array}$ & $\begin{array}{l}\text { Regression models for forecasting small area population } \\
\text { change are proposed which include spatial relationships. } \\
\text { These include the spatially lagged growth rates and } \\
\text { characteristics of nearby areas. The models were tested on } \\
\text { population data for minor civil divisions in Wisconsin, } \\
\text { USA, using data from 1960-1990 to forecast out to } 2000 \text {. } \\
\text { The projection evaluations reveal mixed results and do not } \\
\text { suggest unambiguous preference for the spatiotemporal } \\
\text { regression approach or the extrapolation projection. }\end{array}$ \\
\hline
\end{tabular}




\begin{tabular}{|c|c|}
\hline Reference and URL & Key points \\
\hline $\begin{array}{l}\text { Chi, G., \& Wang, D. (2017). Small- } \\
\text { area population forecasting: a } \\
\text { geographically weighted regression } \\
\text { approach. In D. A. Swanson (Ed.), The } \\
\text { frontiers of applied demography (pp. } \\
\text { 449-471). Springer. } \\
\text { https://doi.org/10.1007/978-3-319- } \\
\text { 43329-5_21 }\end{array}$ & $\begin{array}{l}\text { The authors propose a geographically-weighted regression } \\
\text { (GWR) model to forecast the total populations of small } \\
\text { areas. It was applied to forecast the populations of Minor } \\
\text { Civil Divisions in Wisconsin from } 2000 \text { to } 2010 \text { using a } \\
\text { base period of } 1990-2000 \text {. There were } 33 \text { explanatory } \\
\text { variables; the dependent variable was population growth. } \\
\text { The GWR model was compared to } 4 \text { simple linear and } \\
\text { exponential forecasts. The GWR method provides a novel } \\
\text { estimation of the relationships between population change } \\
\text { and its driving factors, but it underperforms traditional } \\
\text { extrapolation forecasts. }\end{array}$ \\
\hline $\begin{array}{l}\text { Chi, G., Zhou, X., \& Voss, P. R. } \\
\text { (2011). Small-area population } \\
\text { forecasting in an urban setting: a } \\
\text { spatial regression approach. Journal of } \\
\text { Population Research, 28(2-3), 185- } \\
201 . \\
\text { https://doi.org/10.1007/s12546-011- } \\
9053-6\end{array}$ & $\begin{array}{l}\text { The authors report tests of the } 3 \text { types of spatial regression } \\
\text { models of Chi \& Voss (2011) to forecast the total } \\
\text { populations of census tracts in Milwaukee, Wisconsin. The } \\
\text { dependent variable was the population growth rate and } \\
\text { explanatory variables comprised a range of demographic, } \\
\text { socioeconomic, and local area characteristics. Forecasts } \\
\text { were produced for 1990-2000 using data from 1980-90. } \\
\text { Compared to } 4 \text { linear and exponential extrapolations, Mean } \\
\text { Absolute Percentage Errors were found to be slightly lower } \\
\text { for the } 3 \text { spatial regression models. }\end{array}$ \\
\hline $\begin{array}{l}\text { Congdon, P. (2009). Life expectancies } \\
\text { for small areas: A Bayesian random } \\
\text { effects methodology. International } \\
\text { Statistical Review, 77(2), 222-240. } \\
\text { https://doi.org/10.1111/j.1751- } \\
\text { 5823.2009.00080.x }\end{array}$ & $\begin{array}{l}\text { Congdon discusses the advantages of modelling age- } \\
\text { specific mortality rates in small areas using a Bayesian } \\
\text { random effects strategy. The model set up includes random } \\
\text { effects by age, sex and group and allows for correlation } \\
\text { between groups. The modelling strategy was applied to } \\
\text { wards in Eastern England. }\end{array}$ \\
\hline $\begin{array}{l}\text { Congdon, P. (2014). Estimating life } \\
\text { expectancies for US small areas: a } \\
\text { regression framework. Journal of } \\
\text { Geographical Systems, 16(1), 1-18. } \\
\text { https://doi.org/10.1007/s10109-013- } \\
\underline{0177-4}\end{array}$ & $\begin{array}{l}\text { Conventional analyses of small area life expectancies in the } \\
\text { US often require the amalgamation of counties, and do not } \\
\text { take correlations between adjacent ages or areas into } \\
\text { account. The author proposes a method based on a } \\
\text { structured random effects model, which incorporates these } \\
\text { age and area effects. A regression extension allows area } \\
\text { characteristics - such as the ethnic mix, urban-rural level } \\
\text { and socio-economic indices - to be considered. It requires } \\
\text { minimal amalgamation of counties, producing life } \\
\text { expectancy estimates for almost the entire set of counties. } \\
\text { This method was applied to data from US counties to } \\
\text { produce stable life expectancy estimates. }\end{array}$ \\
\hline
\end{tabular}




\begin{tabular}{|c|c|}
\hline Reference and URL & Key points \\
\hline $\begin{array}{l}\text { Dittgen, A., \& Dutreuilh, C. (2005). } \\
\text { Housing and household size in local } \\
\text { population dynamics. Population } \\
\text { (English Edition, 2002-), 60(3), 259- } \\
298 . \\
\text { https://doi.org/10.2307/4148195 }\end{array}$ & $\begin{array}{l}\text { The authors emphasise the relationship between local } \\
\text { populations and housing. Dwelling size influences } \\
\text { household size and age structure. Population forecasts were } \\
\text { prepared for Paris using a cohort-component model which } \\
\text { accounts for fertility, mortality and migration, but has an } \\
\text { additional component for the private household population. } \\
\text { "The population of the additional dwellings that become } \\
\text { available during each 5-year period are added at the end of } \\
\text { each period. To determine this population, the number of } \\
\text { dwellings in question is multiplied by an appropriate } \\
\text { average household size and the result is then broken down } \\
\text { using an appropriate age-sex structure". }\end{array}$ \\
\hline $\begin{array}{l}\text { Dockery, A. M., Harris, M. N., } \\
\text { Holyoak, N., \& Singh, R. B. (2020). A } \\
\text { methodology for projecting sparse } \\
\text { populations and its application to } \\
\text { remote Indigenous communities. } \\
\text { Journal of Geographical Systems, 1- } \\
\text { 25. } \\
\text { https://doi.org/10.1007/s10109-020- } \\
\underline{00329-\mathrm{Z}}\end{array}$ & $\begin{array}{l}\text { The authors propose a model that is effectively a version of } \\
\text { the Hamilton-Perry cohort change model in which the } \\
\text { population is projected by } 5 \text { year age groups and intervals } \\
\text { using cohort change numbers (not ratios). The aim is to be } \\
\text { able to cope with sparse data for very small populations. } \\
\text { Cohort change is projected with a regression model which } \\
\text { uses a range of demographic, social and geographic } \\
\text { variables. A regression model is also used to project the } \\
\text { number of 0-4 year olds, based on population numbers in } \\
\text { older childhood ages. The method was applied to produce } \\
\text { short-term projections of local Indigenous populations by } \\
\text { age and sex in regional and remote parts of Australia. }\end{array}$ \\
\hline $\begin{array}{l}\text { Dyrting, S. (2020). Smoothing } \\
\text { migration intensities with P-TOPALS. } \\
\text { Demographic Research, 43, 1527- } \\
1570 . \\
\text { https://doi.org/10.4054/DemRes.2020. } \\
\underline{43.55}\end{array}$ & $\begin{array}{l}\text { The author introduces a P-TOPALS model framework to } \\
\text { estimate age-specific migration schedules. The framework } \\
\text { combines the classical TOPALS approach, which assumes } \\
\text { an age schedule can be represented as a combination of an } \\
\text { age standard and a spline. Dyrting extends this framework } \\
\text { to estimate the splines using a penalised-spline approach, } \\
\text { which controls the smoothness of the fit with a single } \\
\text { parameter. The method is illustrated on internal migration } \\
\text { rates in the Northern Territory, Australia, across a range of } \\
\text { different population sizes. }\end{array}$ \\
\hline $\begin{array}{l}\text { Foss, W. (2002). Small area population } \\
\text { forcasting. The Appraisal Journal, } \\
70(2), 163 . \\
\text { [No URL] }\end{array}$ & $\begin{array}{l}\text { The paper is an accessible guide to the housing-unit method } \\
\text { and several extrapolation methods for small area total } \\
\text { population forecasts. No new methods are introduced. } \\
\text { Example forecasts are presented. }\end{array}$ \\
\hline
\end{tabular}




\begin{tabular}{|c|c|}
\hline Reference and URL & Key points \\
\hline $\begin{array}{l}\text { Franzén, M., \& Karlsson, T. (2010, 28- } \\
30 \text { April). Using national data to } \\
\text { obtain small area estimators for } \\
\text { population projections on sub-national } \\
\text { level [Paper presentation]. Conference } \\
\text { of European Statisticians, Lisbon, } \\
\text { Portugal. } \\
\text { https://www.unece.org/fileadmin/DAM } \\
\text { Itats/documents/ece/ces/ge.11/2010/sp } \\
\text { 2.e.pdf }\end{array}$ & $\begin{array}{l}\text { The authors propose that migration age-specific input data } \\
\text { for small area cohort-component forecasts be created by } \\
\text { applying national-level data for specific dwelling types. The } \\
\text { assumption is that people living in certain dwelling } \\
\text { type/tenure categories share the same demographic } \\
\text { characteristics throughout the country. Data from the } \\
\text { Swedish population register and real estate register and } \\
\text { cluster analysis was used to identify suitable dwelling types } \\
\text { (33 groups in total). For small area forecasts, the authors } \\
\text { suggest weighting the age profiles by the population } \\
\text { composition of each area. }\end{array}$ \\
\hline $\begin{array}{l}\text { Gonzaga, M. R., \& Schmertmann, C. } \\
\text { P. (2016). Estimating age-and sex- } \\
\text { specific mortality rates for small areas } \\
\text { with TOPALS regression: an } \\
\text { application to Brazil in 2010. Revista } \\
\text { Brasileira de Estudos de População, } \\
\text { 33(3), 629-652. } \\
\text { https://doi.org/10.20947/S0102- } \\
\text { 30982016c0009 }\end{array}$ & $\begin{array}{l}\text { In this paper the authors develop a method to estimate small } \\
\text { area age- and sex-specific mortality rates, based on the } \\
\text { TOPALS relational model. They applied this method to } \\
\text { data from small area in Brazil in } 2010 \text {. This method may be } \\
\text { helpful for making undercount adjustments in small areas } \\
\text { with incomplete death registrations. }\end{array}$ \\
\hline $\begin{array}{l}\text { Gullickson, A., \& Moen, J. (2001). The } \\
\text { use of stochastic methods in local area } \\
\text { population forecasts [Paper } \\
\text { presentation].The annual meeting of } \\
\text { the Population Association of America, } \\
\text { Washington DC. } \\
\text { [No URL] }\end{array}$ & $\begin{array}{l}\text { The authors present probabilistic population forecasts for } \\
\text { one county in Minnesota and the rest of the State. The TFR } \\
\text { is forecast with a random walk with drift model; mortality } \\
\text { is forecast using a Lee-Carter model; net migration is } \\
\text { modelled by randomly sampling from recent crude net } \\
\text { migration rates. Probabilistic forecasts are created by } \\
\text { running a cohort-component model } 1,000 \text { times. The } \\
\text { authors applied the model to produce a probabilistic } \\
\text { forecast of trauma cases at a major hospital in Minneapolis. }\end{array}$ \\
\hline $\begin{array}{l}\text { Hachadoorian, L., Gaffin, S. R., \& } \\
\text { Engelman, R. (2011). Projecting a } \\
\text { gridded population of the world using } \\
\text { ratio methods of trend extrapolation. In } \\
\text { R. P. Cincotta, \& L. J. Gorenflo (Eds.) } \\
\text { Human Population: Its Influences on } \\
\text { Biological Diversity (pp. 13-25). } \\
\text { Springer-Verlag Berlin Heidelberg. } \\
\text { https://www.springer.com/gp/book/978 } \\
3642167065\end{array}$ & $\begin{array}{l}\text { The authors describe how population forecasts for small } \\
\text { grid squares of the World were prepared using } 2 \text { models: } \\
\text { (1) a projected share of national population (shift-share) } \\
\text { model, and (2) and a share of national growth model. Both } \\
\text { models produced some negative populations. A combined } \\
\text { model uses share-of-growth for most countries, and shift- } \\
\text { share for countries where population growth/decline } \\
\text { reverses direction between the base period and the } \\
\text { projection period. Jump-off year populations were obtained } \\
\text { from the Gridded Population of the World dataset and } \\
\text { forecasts were produced for the period 1995-2025. National } \\
\text { projections were those of the UN Population Division. }\end{array}$ \\
\hline
\end{tabular}




\begin{tabular}{|c|c|}
\hline Reference and URL & Key points \\
\hline $\begin{array}{l}\text { Hansen, H.S. (2010). Small-Area } \\
\text { Population Projections - A Key } \\
\text { Element in Knowledge Based e- } \\
\text { Governance. In K.N. Andersen, E. } \\
\text { Francesconi, A. Grönlund, \& T.M. van } \\
\text { Engers (Eds.), EGOVIS 2010. Lecture } \\
\text { Notes in Computer Science: Vol. } 6267 . \\
\text { Electronic Government and the } \\
\text { Information Systems Perspective (pp. } \\
\text { 32-46). Springer, Berlin, Heidelberg. } \\
\text { https://doi.org/10.1007/978-3-642-- } \\
\text { 15172-9 } 4\end{array}$ & $\begin{array}{l}\text { The author describes a cohort-component model for } \\
\text { preparing small area population forecasts. The population } \\
\text { accounting equation (p.35) is unusual in that it separates in- } \\
\text { migration to/from existing dwellings with migration } \\
\text { associated with changes in the dwelling stock. In-migration } \\
\text { of children is not forecast. Local fertility and mortality rates } \\
\text { are prepared by taking regional rates and multiplying by a } \\
\text { local Standardised Fertility/Mortality Ratio. The model is } \\
\text { illustrated with projections for small areas of the } \\
\text { municipality of Randers, Denmark, from } 2007 \text { to } 2020 \text {. }\end{array}$ \\
\hline $\begin{array}{l}\text { Harding, A., Vidyattama, Y., \& } \\
\text { Tanton, R. (2011). Demographic } \\
\text { change and the needs-based planning } \\
\text { of government services: Projecting } \\
\text { small area populations using spatial } \\
\text { microsimulation. Journal of } \\
\text { Population Research, } 28(2-3), 203- \\
224 . \\
\underline{\text { https://doi.org/10.1007/s12546-011- }} \underline{\underline{9061-6}}\end{array}$ & $\begin{array}{l}\text { The authors describe SpatialMSM, a spatial } \\
\text { microsimulation model for Australia which forecasts } \\
\text { population and household characteristics for Statistical } \\
\text { Local Areas (SLAs). It is a static microsimulation model } \\
\text { which involves using Department of Health \& Ageing } \\
\text { macro-level forecasts of SLA populations by age and sex } \\
\text { out to 2027, disaggregating by labour force status, and then } \\
\text { re-weighting the base period small area micro-level dataset } \\
\text { to achieve consistency with the area/age/sex/labour force } \\
\text { forecasts. The paper focuses on likely future changes in } \\
\text { demand for aged care and child care as examples. }\end{array}$ \\
\hline $\begin{array}{l}\text { Hauer, M. E. (2017) Migration induced } \\
\text { by sea-level rise could reshape the US } \\
\text { population landscape. Nature Climate } \\
\text { Change, } 7,321-325 . \\
\text { https://doi.org/10.1038/nclimate } 3271\end{array}$ & $\begin{array}{l}\text { The author presents forecasts of migration flows from } \\
\text { coastal counties in the US which are likely to be subject to } \\
\text { sea-level rise inundation. Populations of those parts of } \\
\text { counties subject to inundation formed the out-migrants; in- } \\
\text { migration to affected countries was reduced in proportion to } \\
\text { the unaffected population of each county. Forecasts were } \\
\text { produced from } 2010 \text { to } 2100 \text {. Unobserved component } \\
\text { modelling was used to project shifts in the migration } \\
\text { system. Florida is projected to experience the largest net } \\
\text { loss of population while Texas is expected to gain the most. }\end{array}$ \\
\hline $\begin{array}{l}\text { Hauer, M. E., Evans, J. M., \& Mishra, } \\
\text { D. R. (2016). Millions projected to be } \\
\text { at risk from sea-level rise in the } \\
\text { continental United States. Nature } \\
\text { Climate Change, 6, 691-695. } \\
\text { https://doi.org/10.1038/nclimate2961 }\end{array}$ & $\begin{array}{l}\text { The authors forecast the population at risk of sea level rise } \\
\text { in the continental United States. Areas expected to be } \\
\text { impacted were modelled using a dynamic flood hazard } \\
\text { model. Population forecasts were made for Census Block } \\
\text { Groups within counties expected to be severely impacted by } \\
\text { sea level rises. A linear/exponential method was used to } \\
\text { forecast the populations from } 2010 \text { to } 2100 \text {, with forecasts } \\
\text { used to calculate populations at risk from sea level rises of } \\
0.9 \mathrm{~m} \text { and } 1.8 \mathrm{~m} \text {. }\end{array}$ \\
\hline
\end{tabular}




\begin{tabular}{|c|c|}
\hline Reference and URL & Key points \\
\hline $\begin{array}{l}\text { Hauer, M. E., Evans, J. M., \& } \\
\text { Alexander, C. R. (2015). Sea-level rise } \\
\text { and sub-county population projections } \\
\text { in coastal Georgia. Population and } \\
\text { Environment, 37(1), 44-62. } \\
\text { https://doi.org/10.1007/s11111-015- } \\
\underline{0233-8}\end{array}$ & $\begin{array}{l}\text { The authors propose a housing-unit population forecasting } \\
\text { method for sub-county areas, and illustrate it with an } \\
\text { application to coastal regions of Georgia, USA. Population } \\
\text { forecasts were combined with separate forecasts of sea- } \\
\text { level rise inundation to estimate the likely impacts of } \\
\text { climate change. The number of dwelling units was forecast } \\
\text { with a linear model for growing areas and exponential } \\
\text { extrapolation for those declining. The models were fitted by } \\
\text { regression and prediction intervals are calculated. }\end{array}$ \\
\hline $\begin{array}{l}\text { Hauer, M. E. (2019). Population } \\
\text { projections for US counties by age, } \\
\text { sex, and race controlled to shared } \\
\text { socioeconomic pathway. Scientific } \\
\text { data, } 6(1), 1-15 . \\
\text { https://doi.org/10.1038/sdata.2019.5 }\end{array}$ & $\begin{array}{l}\text { The author presents forecasts for all US counties by age, } \\
\text { sex and race for } 2020-2100 \text {. The Hamilton-Perry model was } \\
\text { used for private household populations, with one key } \\
\text { variation: cohort change ratios were used for county by race } \\
\text { populations which are declining, while cohort change } \\
\text { differences (absolute numbers) were applied for growing } \\
\text { populations. Both of these were projected with an } \\
\text { ARIMA(0,1,1) model. Populations in group quarters } \\
\text { (institutional dwellings) were assumed to remain constant. } \\
\text { Forecasts were constrained to the Shared Socioeconomic } \\
\text { Pathway scenarios for the US. }\end{array}$ \\
\hline $\begin{array}{l}\text { Inoue, T. (2017). A new method for } \\
\text { estimating small area demographics } \\
\text { and its application to long-term } \\
\text { population projection. In D. A. } \\
\text { Swanson (Ed.), The frontiers of applied } \\
\text { demography (pp. 473-489). Springer. } \\
\text { https://doi.org/10.1007/978-3-319- } \\
\text { W3329-5_22 } \\
\text { Website: http://arcg.is/1GkdZTX }\end{array}$ & $\begin{array}{l}\text { The author proposes a Hamilton-Perry method for small } \\
\text { area population forecasts in which the Cohort Change } \\
\text { Ratios and Child/Woman Ratios are smoothed by } \\
\text { incorporating information from higher geographies } \\
\text { (prefectures). A short-term historical test of this smoothing } \\
\text { method compared to some other approaches (no smoothing; } \\
\text { Empirical Bayes; use of prefecture ratios for all constituent } \\
\text { small areas) showed it to produce the lowest errors. } \\
\text { Population forecasts for } 217,000 \text { small areas in Japan from } \\
2015 \text { to } 2060 \text { were produced. }\end{array}$ \\
\hline $\begin{array}{l}\text { Jannuzzi P (2005) Population } \\
\text { projections for small areas: method and } \\
\text { applications for districts and local } \\
\text { population projections in Brazil. Paper } \\
\text { prepared for the IUSSP conference, } \\
\text { Tours, France. } \\
\text { https://iussp2005.princeton.edu/papers/ } \\
\text { 51422. } \\
\text { Portuguese version of the paper } \\
\text { published at: } \\
\underline{\text { https://doi.org/10.1590/S0102- }} \\
\underline{30982007000100008}\end{array}$ & $\begin{array}{l}\text { The author proposes a coupling of the cohort-component } \\
\text { method at regional levels with a system of differential } \\
\text { equations, based on models of population dynamics used in } \\
\text { ecology, to disaggregate population forecasts to } \\
\text { municipalities. This method works best for projections with } \\
5 \text { and } 10 \text { year forecast horizons for regions with good } \\
\text { census data and vital statistics, but poor-quality small area } \\
\text { data. The method was then applied to small areas in Brazil. }\end{array}$ \\
\hline
\end{tabular}




\begin{tabular}{|c|c|}
\hline Reference and URL & Key points \\
\hline $\begin{array}{l}\text { Jiang, B., Jin, H., Liu, N., Quirk, M., } \\
\text { and Searle, B. (2007). A HMM-based } \\
\text { hierarchical framework for long-term } \\
\text { population projection of small areas. In } \\
\text { M. A. Orgun and J. Thornton (Eds.), } \\
\text { AI 2007: Advances in Artificial } \\
\text { Intelligence. AI 2007. Lecture Notes in } \\
\text { Computer Science, vol } 4830 \text { (pp. 694- } \\
\text { 698). Springer. } \\
\text { https://doi.org/10.1007/978-3-540- } \\
76928-6 \text {-77 }\end{array}$ & $\begin{array}{l}\text { The authors present a small area population forecasting } \\
\text { method which is based on the Hidden-Markov model and } \\
\text { incorporates a hierarchical framework, such that data from } \\
\text { larger geographies are utilised. Compared to the cohort- } \\
\text { component model, the method has fewer data requirements, } \\
\text { is suited to produce longer-term projections, and can } \\
\text { produce prediction intervals and point intervals. The } \\
\text { method was applied to data from the suburbs of Canberra, } \\
\text { Australia, and outperformed both the cohort-component } \\
\text { model and a simple Hidden-Markov model in a 20-year } \\
\text { forecast. }\end{array}$ \\
\hline $\begin{array}{l}\text { Jonker, M. F., van Lenthe, F. J., } \\
\text { Congdon, P. D., Donkers, B., Burdorf, } \\
\text { A., \& Mackenbach, J. P. (2012). } \\
\text { Comparison of Bayesian Random- } \\
\text { Effects and Traditional Life } \\
\text { Expectancy Estimations in Small-Area } \\
\text { Applications. American Journal of } \\
\text { Epidemiology, 176(10), 929-937. } \\
\text { https://doi.org/10.1093/aje/kws152 }\end{array}$ & $\begin{array}{l}\text { Traditional life expectancy estimations tend to generate } \\
\text { unacceptably large biases and standard errors for small } \\
\text { areas with population fewer than 5,000 person years. In this } \\
\text { paper, Monte Carlo simulations were used to demonstrate } \\
\text { that a Bayesian Random-Effects approach outperforms the } \\
\text { traditional approach in small-area settings, allowing } \\
\text { estimates to be produced for populations down to 2,000 } \\
\text { person-years. This improvement is enabled by the Bayesian } \\
\text { method's use of correlations between sexes, geographic } \\
\text { areas and age groups to support estimation of smaller areas } \\
\text { life expectancies. }\end{array}$ \\
\hline $\begin{array}{l}\text { Kanaroglou, P. S., Maoh, H. F., } \\
\text { Newbold, B., Scott, D. M., \& Paez, A. } \\
\text { (2009). A demographic model for } \\
\text { small area population projections: an } \\
\text { application to the Census Metropolitan } \\
\text { Area of Hamilton in Ontario, Canada. } \\
\text { Environment and Planning A: } \\
\text { Economy and Space, 41(4). } 964-979 . \\
\text { https://doi.org/10.1068/a40172 }\end{array}$ & $\begin{array}{l}\text { The authors describe an approach which combines a } \\
\text { multiregional cohort-based demographic model at the } \\
\text { regional scale and an aggregate spatial multinomial logit } \\
\text { model for small areas. The latter distributes in-migrants to } \\
\text { regions to small areas based on migrant and destination area } \\
\text { characteristics, including migrant's age, number of schools, } \\
\text { number of new dwellings, dwelling average rent, distance } \\
\text { to the city centre, and amount of recreational land. The } \\
\text { model was applied to municipalities and their census tracts } \\
\text { in the Hamilton metropolitan region, Canada. }\end{array}$ \\
\hline $\begin{array}{l}\text { Leknes, S., \& Løkken, S. A. (2020). } \\
\text { Empirical Bayes estimation of local } \\
\text { demographic rates. An application } \\
\text { using Norwegian registry data. } \\
\text { Statistics Norway. } \\
\text { https://www.ssb.no/en/befolkning/artik } \\
\text { ler-og-publikasjoner/empirical-bayes- } \\
\text { estimation-of-local-demographic-rates }\end{array}$ & $\begin{array}{l}\text { The authors describe an application of the hierarchical } \\
\text { Empirical Bayes estimation method for estimating small } \\
\text { area demographic rates using full-count Norwegian registry } \\
\text { data. The proposed method is low cost, and efficient, and } \\
\text { supports practitioners in dealing with issues relating to } \\
\text { noisy small area statistics by borrowing statistical strength } \\
\text { from larger area populations, which are used as priors. The } \\
\text { study demonstrates the beneficial properties of the method } \\
\text { in estimating reliable age-specific rates for fertility, } \\
\text { mortality, internal migration, and international migration at } \\
\text { the small area scale. }\end{array}$ \\
\hline
\end{tabular}




\begin{tabular}{|c|c|}
\hline Reference and URL & Key points \\
\hline $\begin{array}{l}\text { Li, T., \& Corcoran, J. (2011). Testing } \\
\text { dasymetric techniques to spatially } \\
\text { disaggregate the regional population } \\
\text { forecasts for South East Queensland. } \\
\text { Journal of Spatial Science, 56(2), 203- } \\
221 . \\
\underline{\text { https://doi.org/10.1080/14498596.2011 }} \\
.623343\end{array}$ & $\begin{array}{l}\text { The paper describes how dasymetric methods can be used } \\
\text { to disaggregate regional population forecasts to small areas. } \\
\text { Several alternative dasymetric methods were tested on the } \\
\text { metropolitan region of South East Queensland, Australia. } \\
\text { Local population forecasts were distributed to Statistical } \\
\text { Local Areas based on their dwelling density category, with } \\
\text { each density category assigned a proportion of regional } \\
\text { population growth. A method involving } 4 \text { density classes } \\
\text { was found to produce the best results. }\end{array}$ \\
\hline $\begin{array}{l}\text { Lomax, N., \& Smith, A. (2017). } \\
\text { Microsimulation for demography. } \\
\text { Australian Population Studies, 1(1), } \\
\text { 73-85. } \\
\text { https://doi.org/10.37970/aps.v1i1.14 }\end{array}$ & $\begin{array}{l}\text { The authors describe the utility of microsimulation for } \\
\text { population forecasting. They demonstrate how static } \\
\text { microsimulation can be used to produce a synthetic } \\
\text { population of individuals with characteristics describing } \\
\text { age, sex, ethnicity, and location using an example from the } \\
\text { London borough of Tower Hamlets, at the Middle-layer } \\
\text { Super Output Area geographic level (average population } \\
8,000 \text { persons). This synthetic population is then used the } \\
\text { base population for a dynamic microsimulation which } \\
\text { projects the population into the future. Data inputs included } \\
\text { UK census data and R code is provided to support } \\
\text { microsimulations. }\end{array}$ \\
\hline $\begin{array}{l}\text { Marois, G., \& Bélanger, A. (2014). } \\
\text { Microsimulation Model Projecting } \\
\text { Small Area Populations Using } \\
\text { Contextual Variables: An Application } \\
\text { to the Montreal Metropolitan Area, } \\
\text { 2006-2031. International Journal of } \\
\text { Microsimulation, 7(1), 158-193. } \\
\text { https://doi.org/10.34196/ijm.00097 }\end{array}$ & $\begin{array}{l}\text { The authors present results from a dynamic } \\
\text { microsimulation model projecting the population for } 79 \\
\text { municipalities in Montreal from } 2006 \text { to } 2031 \text {. The core } \\
\text { innovation of the model is the modelling of location- } \\
\text { specific migration probabilities, with destination choice } \\
\text { modelled as a function of distance to the city, current } \\
\text { municipality size, municipality development potential, } \\
\text { population composition as well as its geographic location. } \\
\text { Conditional logistic regression was used to estimate the } \\
\text { mobility parameters including in the microsimulation } \\
\text { model. Model validation of the population forecasts over a } \\
5 \text { year horizon showed a mean absolute percentage error of } \\
3.4 \% \text {, but higher for smaller populations. Overall, the } \\
\text { authors conclude the population forecast errors are within } \\
\text { reasonable } 10 \text { year error bands }\end{array}$ \\
\hline
\end{tabular}




\begin{tabular}{|c|c|}
\hline Reference and URL & Key points \\
\hline $\begin{array}{l}\text { Marois, G., \& Bélanger, A. (2015). } \\
\text { Analyzing the impact of urban } \\
\text { planning on population distribution in } \\
\text { the Montreal metropolitan area using a } \\
\text { small-area microsimulation projection } \\
\text { model. Population Environment, 37(2), } \\
\text { 131-156. } \\
\text { https://doi.org/10.1007/s11111-015- } \\
\text { 0234-7 }\end{array}$ & $\begin{array}{l}\text { The authors describe a microsimulation model to forecast } \\
\text { the population of Montreal from } 2016 \text { to } 2031 \text { and assess } \\
\text { the impacts of changes in urban planning upon the spatial } \\
\text { distribution of population. Three metropolitan development } \\
\text { scenarios were considered: a baseline using the urban plan } \\
\text { to indicate planned new housing units; an alternative in } \\
\text { which the number of housing units is halved in the suburbs } \\
\text { and increased in the core; and a final in which new housing } \\
\text { is also reduced in the central core. The authors conclude } \\
\text { that urban sprawl cannot be avoided, but that its speed can } \\
\text { be reduced through planning choices. Validation of the } \\
\text { forecast populations over the 2006-2011 period indicated } \\
\text { satisfactory performance - mean percentage error of } 3.4 \% \text {. } \\
\text { The authors note that due to data limitations and well as } \\
\text { burdensome computation requirements, forecasts below the } \\
\text { municipality level were problematic. }\end{array}$ \\
\hline $\begin{array}{l}\text { Marshall, A., \& Simpson, L. (2009). } \\
\text { Population sustainability in rural } \\
\text { communities: The case of two British } \\
\text { national parks. Applied Spatial } \\
\text { Analysis Policy, 2(2), 107-127. } \\
\text { https://doi.org/10.1007/s12061-008- } \\
\underline{9017-1}\end{array}$ & $\begin{array}{l}\text { The authors present population and household forecasts for } \\
\text { two UK national park areas. Considerable input data } \\
\text { estimation was required due to the non-standard } \\
\text { geographies used. National age-specific rates for fertility } \\
\text { and mortality were created by scaling national rates to local } \\
\text { summary indicators (e.g. TFR). Forecasts were produced } \\
\text { using the POPGROUP software. The projection models } \\
\text { were a cohort-component model using net migration rates } \\
\text { and a headship rate household model. Dwelling-led } \\
\text { projections were also created. The projection model adjusts } \\
\text { migration to produce population and household forecasts } \\
\text { consistent with the assumed dwelling numbers. }\end{array}$ \\
\hline $\begin{array}{l}\text { McKee, J. J., Rose, A. N., Bright, E. } \\
\text { A., Huynh, T., \& Bhaduri, B. L. } \\
\text { (2015). Locally adaptive, spatially } \\
\text { explicit projection of US population } \\
\text { for } 2030 \text { and } 2050 \text {. Proceedings of the } \\
\text { National Academy of Sciences, } 112(5) \text {, } \\
1344-1349 . \\
\text { https://doi.org/10.1073/pnas.14057131 } \\
\underline{12}\end{array}$ & $\begin{array}{l}\text { Population forecasts for the contiguous USA were produced } \\
\text { for } 30 \text { arc second grid squares for } 2030 \text { and } 2050 \text {. } \\
\text { Projections were first produced at the county scale from } \\
2010 \text { to } 2050 \text { using a cohort-component model with net } \\
\text { migration rates (though the rates had to be age- and sex- } \\
\text { invariant due to data limitations). Constraining to US } \\
\text { Census Bureau national and State projections was then } \\
\text { applied. Then, projections were spatially disaggregated } \\
\text { using a "potential development coefficient" based on } \\
\text { several variables, including land use and slope, roads, urban } \\
\text { accessibility, and current population. }\end{array}$ \\
\hline
\end{tabular}




\begin{tabular}{|c|c|}
\hline Reference and URL & Key points \\
\hline $\begin{array}{l}\text { Merkens, J. L., Reimann, L., Hinkel, J., } \\
\& \text { Vafeidis, A. T. (2016). Gridded } \\
\text { population projections for the coastal } \\
\text { zone under the Shared Socioeconomic } \\
\text { Pathways. Global and Planetary } \\
\text { Change, 145, 57-66. } \\
\text { https://doi.org/10.1016/j.gloplacha.201 } \\
6.08 .009\end{array}$ & $\begin{array}{l}\text { The authors describe how spatially detailed population } \\
\text { forecasts of coastal populations were produced. Forecasts of } \\
\text { total population were produced for grid squares } 30 \text { arc- } \\
\text { seconds in size (about } 1 \mathrm{~km}^{2} \text { at the equator) from } 2000 \text { to } \\
2100 \text {, which are consistent with the } 5 \text { basic Shared } \\
\text { Socioeconomic Pathways. The method splits each country } \\
\text { into } 4 \text { 'zones' (coastal-urban, coastal-rural, inland-urban, } \\
\text { and inland-rural) and assumes recent growth rate } \\
\text { differences continue into the future, with forecasts } \\
\text { constrained to independent national population forecasts } \\
\text { and urbanisation forecasts. Grid square forecasts are created } \\
\text { by assuming the grid square population grows at the same } \\
\text { rate as the zonal population. }\end{array}$ \\
\hline $\begin{array}{l}\text { Rayer, S. (2008). Population Forecast } \\
\text { Errors: A Primer for Planners. Journal } \\
\text { of Planning Education and Research, } \\
\text { 27(4), 417-430. } \\
\text { https://doi.org/10.1177/0739456x0731 } \\
\text { 3925 }\end{array}$ & $\begin{array}{l}\text { The author reports tests of various population forecasting } \\
\text { methods and their errors. Forecasts of total county } \\
\text { populations across the USA were created using five simple } \\
\text { methods and two averaged methods (one an average of all } 5 \\
\text { individual methods; the other a trimmed mean of } 3 \text { ). The } \\
\text { averaged forecasts were overall as good as, or marginally } \\
\text { more accurate, than any individual method. Extending the } \\
\text { length of the base period beyond } 10 \text { years had little effect } \\
\text { on accuracy. Composite methods, where different methods } \\
\text { were used for areas according to their base period growth } \\
\text { rates, also gave reasonable outcomes. }\end{array}$ \\
\hline $\begin{array}{l}\text { Rayer, S. (2015). Demographic } \\
\text { Techniques: Small-area estimates and } \\
\text { projections. In J. D Wright (Ed.), } \\
\text { International Encyclopedia of the } \\
\text { Social \& Behavioral Sciences ( } 2^{\text {nd }} \text { ed., } \\
\text { pp. 162-169). Elsevier. } \\
\text { https://doi.org/10.1016/B978-0-08- } \\
\underline{097086-8.31015-7}\end{array}$ & $\begin{array}{l}\text { This encyclopedia entry reviews methods for small area } \\
\text { population forecasting and discusses the associated } \\
\text { challenges, definitions of smallness, and the data sources } \\
\text { that are used. Also outlined are recent developments } \\
\text { concerning the incorporation of data from geographic } \\
\text { information systems, which allow populations to be } \\
\text { estimated and projected for user-defined regions, and allow } \\
\text { demographers to make projections which aren't restricted } \\
\text { by administrative boundaries. }\end{array}$ \\
\hline $\begin{array}{l}\text { Rayer, S., Smith, S. K., \& Tayman, J. } \\
\text { (2009). Empirical prediction intervals } \\
\text { for county population forecasts. } \\
\text { Population Research Policy Review, } \\
28(6), 773 . \\
\text { https://doi.org/10.1007/s11113-009- } \\
9128-7\end{array}$ & $\begin{array}{l}\text { A method for creating prediction intervals for small area } \\
\text { population forecasts is presented. The authors created a } \\
\text { population forecasts for } 2,482 \text { US counties over several past } \\
\text { decades using } 7 \text { trend extrapolation methods and a trimmed } \\
\text { mean of these; calculated forecast errors from the trimmed } \\
\text { mean forecasts; and then used these to create empirical } \\
\text { prediction intervals. } 90 \text { th percentile intervals based on } \\
\text { recent past errors were evaluated as good predictions of the } \\
\text { magnitude of error in subsequent forecasts. }\end{array}$ \\
\hline
\end{tabular}




\begin{tabular}{|c|c|}
\hline Reference and URL & Key points \\
\hline $\begin{array}{l}\text { Rayer, S., \& Smith, S. K. (2010). } \\
\text { Factors affecting the accuracy of } \\
\text { subcounty population forecasts. } \\
\text { Journal of Planning Education } \\
\text { Research, 30(2), 147-161. } \\
\text { https://doi.org/10.1177/0739456X1038 } \\
\underline{0056}\end{array}$ & $\begin{array}{l}\text { The paper reports an analysis of subcounty population } \\
\text { forecast errors in Florida. The authors found that } 10 \text { years } \\
\text { of base period data is sufficient to gain maximum accuracy } \\
\text { using extrapolative methods. Forecast errors were large for } \\
\text { the smallest populations and those with high rates of } \\
\text { population change. Errors were lowest for areas which } \\
\text { experienced moderate base period population change, and } \\
\text { improvements in accuracy were achieved by using trimmed } \\
\text { means of several methods. }\end{array}$ \\
\hline $\begin{array}{l}\text { Reinhold, M., \& Thomsen, S. L. } \\
\text { (2015). Subnational population } \\
\text { projections by age: An evaluation of } \\
\text { combined forecast techniques. } \\
\text { Population Research Policy Review, } \\
\text { 34(4), 593-613. } \\
\text { https://doi.org/10.1007/s11113-015- } \\
9362-0\end{array}$ & $\begin{array}{l}\text { The authors describe a forecasting approach which takes the } \\
\text { average of } 7 \text { sets of cohort-component projections. They } \\
\text { use the common cohort-component model as the reference } \\
\text { case and additionally consider six variants. These variants } \\
\text { are: cohort-component with migration, cohort-component } \\
\text { without migration, and the cohort-component model } \\
\text { constrained to total populations from linear, no change, } \\
\text { projected share-of-population, and constant share-of- } \\
\text { population models. Several sets of retrospective forecasts } \\
\text { were created for districts in the state of Lower Saxony, } \\
\text { Germany, for } 10 \text { year horizons. The averaged results proved } \\
\text { marginally more accurate than any of the individual } \\
\text { methods. }\end{array}$ \\
\hline $\begin{array}{l}\text { Riiman, V., Wilson, A., Milewicz, R., } \\
\text { \& Pirkelbauer, P. (2019). Comparing } \\
\text { Artificial Neural Network and Cohort- } \\
\text { Component Models for Population } \\
\text { Forecasts. Population Review, 58(2), } \\
\text { 100-116. } \\
\text { https://doi.org/10.1353/prv.2019.0008 }\end{array}$ & $\begin{array}{l}\text { This paper compared total population forecasts created by } \\
\text { long short-term memory (LSTM) models with those } \\
\text { generated by a cohort component model, for counties in } \\
\text { Alabama, USA. Data used included decennial census data } \\
\text { and annual mid-year intercensal population data. Separate } \\
\text { forecasts were produced for these data types. Two training } \\
\text { regimes were tried: training models on data from all } \\
\text { counties and training separate models for each county. Data } \\
\text { until } 2000 \text { was used for training, with forecasts made to } \\
\text { 2010. Single-country LSTM models trained with decennial } \\
\text { data performed better than the Cohort Component Model. } \\
\text { Other LSTM models and single-county model trained with } \\
\text { mid-year data produced comparable or worse forecasts, } \\
\text { depending on error measures used. }\end{array}$ \\
\hline
\end{tabular}




\begin{tabular}{|c|c|}
\hline Reference and URL & Key points \\
\hline $\begin{array}{l}\text { Scherbov, S., \& Ediev, D. (2011). } \\
\text { Significance of life table estimates for } \\
\text { small populations: Simulation-based } \\
\text { study of standard errors. Demographic } \\
\text { Research, 24(22), 527-550. } \\
\text { https://doi.org/10.4054/DemRes.2011. } \\
\underline{24.22}\end{array}$ & $\begin{array}{l}\text { The authors present an analysis of bias, standard errors and } \\
\text { distribution of characteristics of lifetables for small } \\
\text { populations. Simulation methods are presented for the case } \\
\text { of both stationary (from } \mathrm{N}=1,000 \text { to } 1 \text { million) and stable } \\
\text { populations ( } \mathrm{r}=-2 \% \text { to } 2 \% \text { ) with } 25,000 \text { simulations } \\
\text { included to reduce the likelihood of statistical errors. } \\
\text { Findings and recommendations include: (1) estimation bias } \\
\text { and standard errors become too high for general use from a } \\
\text { population of 5,000 or lower - with the estimation of } \\
\text { confidence intervals and other statistical analyses not } \\
\text { plausible, (2) population age composition is critical to the } \\
\text { accuracy of estimating life expectancy in small populations, } \\
\text { (3) there are no advantages in the use of abridged over } \\
\text { unabridged lifetables, even with sparse age of death data, } \\
\text { and (4) the exact procedure used for open age intervals is } \\
\text { critical to life expectancy calculation in small populations. }\end{array}$ \\
\hline $\begin{array}{l}\text { Schmertmann, C. P., Cavenaghi, S. M., } \\
\text { Assunção, R. M., \& Potter, J. E. } \\
\text { (2013). Bayes plus Brass: estimating } \\
\text { total fertility for many small areas from } \\
\text { sparse census data. Population studies, } \\
67(3), 255-273 \text {. } \\
\underline{\text { https://doi.org/10.1080/00324728.2013 }} \\
\underline{795602}\end{array}$ & $\begin{array}{l}\text { The authors propose a new method for estimating small } \\
\text { area total fertility which tackles sparse data challenges, and } \\
\text { is automated and reproducible. This method uses Empirical } \\
\text { Bayes methods in order to smooth local age-specific rates } \\
\text { by borrowing strength from neighbouring areas. Then a } \\
\text { variant of Brass's P/F parity correction procedure is } \\
\text { applied. The method was applied to data from over 5,000 } \\
\text { municipalities in Brazil, using Brazilian Census data from } \\
2000 \text {. }\end{array}$ \\
\hline $\begin{array}{l}\text { Schmertmann, C. P., \& Hauer, M. E. } \\
\text { (2019). Bayesian estimation of total } \\
\text { fertility from a population's age--sex } \\
\text { structure. Statistical Modelling, } 19(3), \\
225-247 \text {. } \\
\text { https://doi.org/10.1177/1471082X1880 } \\
\underline{1450}\end{array}$ & $\begin{array}{l}\text { Good quality births data often do not exist, rendering } \\
\text { estimates of the Total Fertility Rates very difficult. The } \\
\text { authors explore the relationship between Total Fertility } \\
\text { Rates and the Child/Woman Ratio. They develop a } \\
\text { Bayesian approach to estimating TFR from age structures, } \\
\text { using demographic information from sources such as the } \\
\text { Human Fertility Database as prior inputs to the model. They } \\
\text { illustrate their model with an application to an Indigenous } \\
\text { population in Brazil and to counties in Georgia, USA. }\end{array}$ \\
\hline $\begin{array}{l}\text { Simpson, L. (2017). Integrated local } \\
\text { demographic forecasts constrained by } \\
\text { the supply of housing or jobs: Practice } \\
\text { in the UK. In D. A. Swanson (Ed.), } \\
\text { The frontiers of applied demography } \\
\text { (pp. 329-350). Springer. } \\
\text { https://doi.org/10.1007/978-3-319- } \\
\text { 43329-5_16 }\end{array}$ & $\begin{array}{l}\text { Methods are presented for constraining a local area cohort- } \\
\text { component population forecast to assumed numbers of } \\
\text { dwellings or jobs. Consistency with either future dwelling } \\
\text { or job numbers is achieved by adjusting migration flows, } \\
\text { which in turn affects future births and deaths. The extent to } \\
\text { which the inward rather than outward migration flows are } \\
\text { adjusted, and local rather than overseas flows, is set by } \\
\text { user-defined weights. Example forecasts were produced by } \\
\text { the POPGROUP software, which incorporates the } \\
\text { adjustment mechanisms. }\end{array}$ \\
\hline
\end{tabular}




\begin{tabular}{|c|c|}
\hline Reference and URL & Key points \\
\hline $\begin{array}{l}\text { Simpson, L., \& Snowling, H. (2011). } \\
\text { Estimation of local demographic } \\
\text { variation in a flexible framework for } \\
\text { population projections. Journal of } \\
\text { Population Research, 28(2-3), 109- } \\
127 . \\
\underline{\text { https://doi.org/10.1007/s12546-011- }} \\
\underline{9060-7}\end{array}$ & $\begin{array}{l}\text { Three ways of preparing input data for small area cohort- } \\
\text { component forecasts are assessed for situations where age- } \\
\text { specific fertility, mortality and migration data are } \\
\text { unavailable, or available but prohibitively expensive or } \\
\text { confidential. The No Local Variation option applies the } \\
\text { wider region's fertility and mortality age profiles of rates } \\
\text { and the same pair of in- and out-migration age profiles to } \\
\text { all small areas. The Local Calibration option creates small } \\
\text { area assumptions from a short-run training projection which } \\
\text { constrains the No Local Variation assumptions using total } \\
\text { recorded births and deaths in each area, and estimates age- } \\
\text { sex specific migration from adjacent population estimates } \\
\text { by age and sex. The Local Direct comparison projection } \\
\text { uses small area fertility, mortality and migration age } \\
\text { profiles of rates, directly estimated from data available to } \\
\text { government. After empirical testing, the authors conclude } \\
\text { that the Local Calibration option provides the most } \\
\text { plausible forecasts. }\end{array}$ \\
\hline $\begin{array}{l}\text { Smith, S. K., Tayman, J., \& Swanson, } \\
\text { D. A. (2013). A practitioner's guide to } \\
\text { state and local population projections. } \\
\text { Springer. } \\
\text { https://www.springer.com/gp/book/978 } \\
9400775503\end{array}$ & $\begin{array}{l}\text { This book provides a comprehensive guide to the } \\
\text { preparation of State/regional, local and small area } \\
\text { population forecasts. It includes a detailed account of } \\
\text { various types of cohort-component model, simple } \\
\text { extrapolative models, structural models, and } \\
\text { microsimulation models, as well as derived projections } \\
\text { (school enrolments, households, labour force, etc.). It } \\
\text { covers the preparation of fertility, mortality, and migration } \\
\text { assumptions, and lots of practical advice on evaluating } \\
\text { forecasts, special adjustments, forecast accuracy and } \\
\text { uncertainty, model selection, and documentation. }\end{array}$ \\
\hline $\begin{array}{l}\text { Stimson, R., Bell, M., Corcoran, J., \& } \\
\text { Pullar, D. (2012). Using a large scale } \\
\text { urban model to test planning scenarios } \\
\text { in the Brisbane-South East Queensland } \\
\text { region. Regional Science Policy \& } \\
\text { Practice, 4(4), 373-392. } \\
\text { https://doi.org/10.1111/j.1757- } \\
7802.2012 .01082 . \mathrm{x}\end{array}$ & $\begin{array}{l}\text { The authors describe a large-scale urban model to forecast } \\
\text { population, dwellings, employment and other variables for } \\
\text { the South East Queensland region of Australia over the } \\
\text { period } 2001 \text { to } 2026 \text {. Regional-level forecasts of dwellings } \\
\text { and population are disaggregated to small areas via a land } \\
\text { use development model of housing which considers (i) } \\
\text { residential land capacity, (ii) proximity to existing } \\
\text { development, and (iii) the accessibility of local areas to } \\
\text { services. The purpose of the model was to support } \\
\text { metropolitan regional planning and permit the assessment } \\
\text { of alternative planning scenarios. }\end{array}$ \\
\hline
\end{tabular}




\begin{tabular}{|c|c|}
\hline Reference and URL & Key points \\
\hline $\begin{array}{l}\text { Striessnig, E., Gao, J., O’Neill, B. C., } \\
\text { \& Jiang, L. (2019). Empirically based } \\
\text { spatial projections of US population } \\
\text { age structure consistent with the shared } \\
\text { socioeconomic pathways. } \\
\text { Environmental Research Letters, } \\
\text { 14(11), 114038. } \\
\text { https://doi.org/10.1088/1748- } \\
\text { 9326/ab4a3a }\end{array}$ & $\begin{array}{l}\text { The authors describe the preparation of county population } \\
\text { forecasts by broad age group across the USA consistent } \\
\text { with various Shared Socioeconomic Pathway scenarios for } \\
\text { the period 2010-2100. Instead of the cohort-component } \\
\text { model, machine learning regression trees were used to } \\
\text { forecast the share of a county's population in each age } \\
\text { group based on past demographic characteristics. The } \\
\text { model was trained using } 1980-2000 \text { census data and tested } \\
\text { over the } 2000-2010 \text { period. This demonstrated a good fit. } \\
\text { National projections by age and local population totals were } \\
\text { obtained from elsewhere. }\end{array}$ \\
\hline $\begin{array}{l}\text { Swanson, D. A., Schlottmann, A., \& } \\
\text { Schmidt, B. (2010). Forecasting the } \\
\text { population of census tracts by age and } \\
\text { sex: An example of the Hamilton- } \\
\text { Perry method in action. Population } \\
\text { Research Policy Review, 29(1), 47-63. } \\
\text { https://doi.org/10.1007/s11113-009- } \\
9144-7\end{array}$ & $\begin{array}{l}\text { The authors describe the preparation of population forecasts } \\
\text { for census tracts and block groups in Clark County, } \\
\text { Nevada, for the period 2000-2020. They applied the } \\
\text { Hamilton-Perry shortcut cohort model with some } \\
\text { constraints. Cohort Change Ratios were estimated from } \\
\text { 1990-2000 population change, with adjustments applied by } \\
\text { controlling forecasts to census tract population estimates for } \\
\text { 2004. Ceiling and floor limits were also applied between } \\
2005 \text { and } 2020 \text { to prevent growth becoming too high or } \\
\text { low. The paper includes a discussion of how demographers } \\
\text { preparing forecasts work with a client to best meet their } \\
\text { needs. }\end{array}$ \\
\hline $\begin{array}{l}\text { Tayman, J. (2011). Assessing } \\
\text { uncertainty in small area forecasts: } \\
\text { State of the practice and } \\
\text { implementation strategy. Population } \\
\text { Research Policy Review, 30(5), 781- } \\
\text { 800. } \\
\text { https://doi.org/10.1007/s11113-011- } \\
\underline{9210-9}\end{array}$ & $\begin{array}{l}\text { This paper presents a review of current practices in } \\
\text { quantifying the uncertainty of small area population } \\
\text { forecasts. They include: (1) alternative scenarios, }(2) \\
\text { prediction intervals (both model-based and empirically- } \\
\text { based), and (3) expert judgment. The author then goes on to } \\
\text { describe some practical ways of implementing these } \\
\text { methods, and makes suggestions for further research in this } \\
\text { area. }\end{array}$ \\
\hline $\begin{array}{l}\text { Tayman, J., \& Swanson, D. A. (2017). } \\
\text { Using modified cohort change and } \\
\text { child-woman ratios in the Hamilton- } \\
\text { Perry forecasting method. Journal of } \\
\text { Population Research, 34(3), 209-231. } \\
\text { https://doi.org/10.1007/s12546-017- } \\
9190-7\end{array}$ & $\begin{array}{l}\text { The authors develop variations of the Hamilton-Perry } \\
\text { where the Cohort Change Ratios and Child/Woman Ratios } \\
\text { are modified through averaging, trending, or through a } \\
\text { synthetic method that applies state-level changes of the } \\
\text { ratios. These approaches were then compared against the } \\
\text { standard Hamilton-Perry method where the ratios are kept } \\
\text { constant. The analysis was undertaken on data for } \\
\text { Washington State counties and New Mexico census tracts. } \\
\text { Errors were reduced with the synthetic method, but not } \\
\text { through averaging and trending the ratios. }\end{array}$ \\
\hline
\end{tabular}




\begin{tabular}{|c|c|}
\hline Reference and URL & Key points \\
\hline $\begin{array}{l}\text { Vasan, S., Baker, J., \& Alcántara, A. } \\
\text { (2018). Use of Kernel Density and } \\
\text { Raster Manipulation in GIS to Predict } \\
\text { Population in New Mexico Census } \\
\text { Tracts. Review of Economics Finance, } \\
\text { 14, 25-38. } \\
\text { http://www.bapress.ca/ref/ref- } \\
\underline{\text { article/1923-7529-2018-04-25-14.pdf }}\end{array}$ & $\begin{array}{l}\text { Boundary changes pose significant problems for small area } \\
\text { population estimates and forecasts. This paper presents a } \\
\text { method which uses kernel functions to disaggregate } \\
\text { population data from census block counts into tiny pixels in } \\
\text { GIS software. Population data can then be re-aggregated } \\
\text { back to any larger geography. This approach was used to } \\
\text { convert } 1990 \text { and } 2000 \text { census block counts in New Mexico } \\
\text { into data based on } 2010 \text { census boundaries. The converted } \\
\text { geography data was used to estimate } 1990-2000 \text { population } \\
\text { change, and then census block population forecasts were } \\
\text { created from } 2000 \text { to } 2010 \text {. Evaluation against } 2010 \text { census } \\
\text { data showed a mean absolute percentage error of } 142 \% \text { for } \\
\text { census blocks and } 30 \% \text { for census tracts. }\end{array}$ \\
\hline $\begin{array}{l}\text { Vidyattama, Y., \& Tanton, R. (2010). } \\
\text { Projecting Small Area Statistics with } \\
\text { Australian Microsimulation Model } \\
\text { (SPATIALMSM). Australasian } \\
\text { Journal of Regional Studies, 16(1), 99- } \\
126 . \\
\text { https://www.anzrsai.org/assets/Uploads } \\
\text { PublicationChapter/416- } \\
\text { Vidyattama.pdf }\end{array}$ & $\begin{array}{l}\text { The authors describe the use of a spatial microsimulation } \\
\text { model to project small area socio-economic statistics. } \\
\text { Specifically, a static ageing spatial microsimulation is } \\
\text { presented for Australia at the Statistical Local Area (SLA) } \\
\text { level. The model reweights respondents from } 2002 / 03 \text { and } \\
\text { 2003/04 Survey of Income and Housing to } 2006 \text { Census of } \\
\text { Population and Housing SLA benchmarks using iterative } \\
\text { constrained optimisation techniques. }\end{array}$ \\
\hline $\begin{array}{l}\text { Walters, A., \& Cai, Q. (2008). } \\
\text { Investigating the use of holt-winters } \\
\text { time series model for forecasting } \\
\text { population at the state and sub-state } \\
\text { levels. Paper presented at the } \\
\text { Population Association of America } \\
2008 \text { Annual Meeting Program, New } \\
\text { Orleans, LA. } \\
\text { https://paa2008.princeton.edu/papers/8 } \\
\underline{0184}\end{array}$ & $\begin{array}{l}\text { The paper describes the performance of the Holt-Winters } \\
\text { (exponential smoothing) model, ARIMA models, and } \\
\text { simple extrapolative models (linear and exponential) for } \\
\text { forecasting total populations. Retrospective forecasts were } \\
\text { created for US states, and counties and planning districts in } \\
\text { Virginia, USA. Differences in average errors were modest, } \\
\text { though Holt-Winters was most accurate overall for } 5 \text { year } \\
\text { forecast horizons and the exponential model for } 10 \text { year } \\
\text { horizons. The authors conclude that the "Holt-Winters } \\
\text { model provides both feasible and accurate population } \\
\text { forecasts at the state and sub-state levels." }\end{array}$ \\
\hline $\begin{array}{l}\text { Weber, H. (2020). How Well Can the } \\
\text { Migration Component of Regional } \\
\text { Population Change be Predicted? A } \\
\text { Machine Learning Approach Applied } \\
\text { to German Municipalities. } \\
\text { Comparative Population Studies, } 45 . \\
\text { https://doi.org/10.12765/CPoS-2020- } \\
\underline{08}\end{array}$ & $\begin{array}{l}\text { The authors present several models to predict within- } \\
\text { country and international migration at the municipal level in } \\
\text { Germany. The evaluation included regression, decision tree, } \\
\text { random forest, and neural network models. Data from } 2005 \text { - } \\
2009 \text { were used to train the models and support the } \\
\text { prediction of net migration rates for the } 2011-2015 \text { period. } \\
\text { The data included socio-economic and demographic } \\
\text { indicators, and other characteristics (e.g. distance to } \\
\text { universities). The correlations of the predicted net migration } \\
\text { rate for 'education migration' (ages } 18-24 \text { ) with actual } \\
\text { migration data was } \mathrm{R}^{2}>0.5 \text { while for 'family migration' } \\
\text { (ages } 0-17 \text { and } 30-49) \mathrm{R}^{2}=0.25 \text {. }\end{array}$ \\
\hline
\end{tabular}




\begin{tabular}{|c|c|}
\hline Reference and URL & Key points \\
\hline $\begin{array}{l}\text { Wilson, T. (2011). A review of sub- } \\
\text { regional population projection } \\
\text { methods. Queensland Centre for } \\
\text { Population Research, The University } \\
\text { of Queensland. } \\
\text { https://www.researchgate.net/publicati } \\
\underline{\text { on/279535374_A_Review_of_Sub- }} \\
\underline{\text { Regional_Population_Projection_Meth }} \\
\underline{\text { ods }}\end{array}$ & $\begin{array}{l}\text { This report reviews many local and small area population } \\
\text { forecasting methods, including: trend extrapolation, time } \\
\text { series models, regression approaches, simple component } \\
\text { methods, economic base methods, the housing-unit model, } \\
\text { land use models, shortcut component methods, cohort- } \\
\text { component models, and microsimulation. It also considers } \\
\text { averaged methods, integrated methods which involve } \\
\text { several connected models, and the projection of migration } \\
\text { in cohort-component models. Methods are reviewed } \\
\text { according to several criteria relevant to state government } \\
\text { demographers selecting an optimum projection method. }\end{array}$ \\
\hline $\begin{array}{l}\text { Wilson, T. (2015). New evaluations of } \\
\text { simple models for small area } \\
\text { population forecasts. Population, } \\
\text { Space and Place, 21(4), 335-353. } \\
\text { https://doi.org/10.1002/psp.1847 }\end{array}$ & $\begin{array}{l}\text { The paper presents an evaluation of simple methods for } \\
\text { forecasting the total populations of small areas. The } \\
\text { selected methods consisted of } 10 \text { individual models, } \\
\text { averages of every combination of } 2,3,4 \text { and } 5 \text { models, and } \\
\text { composite approaches which use different models } \\
\text { depending on population size and recent growth rates. } \\
\text { Example small area population forecasts for Australia, New } \\
\text { Zealand, and England \& Wales were evaluated. A small } \\
\text { proportion of averaged and composite models proved more } \\
\text { accurate than the best individual models, supporting other } \\
\text { research which has found that model combining improves } \\
\text { accuracy. }\end{array}$ \\
\hline $\begin{array}{l}\text { Wilson, T. (2014). Simplifying Local } \\
\text { Area Population and Household } \\
\text { Projections with POPART. In M. N. } \\
\text { Hoque \& L. B. Potter (Eds.), Emerging } \\
\text { Techniques in Applied Demography } \\
\text { (pp. 25-38). Springer Netherlands. } \\
\text { http://dx.doi.org/10.1007/978-94-017- } \\
\underline{8990-5 \_3}\end{array}$ & $\begin{array}{l}\text { The chapter describes POPART, an Excel/VBA projection } \\
\text { program for individual local or small areas. It includes a bi- } \\
\text { regional cohort-component model (based on transition } \\
\text { population accounts) with } 5 \text { year age group and time } \\
\text { intervals, and a householder rate household model. It was } \\
\text { designed to simplify the projections process by only using } \\
\text { publicly available input data, providing a user-friendly } \\
\text { interface with pull-down menus and buttons, and simple } \\
\text { assumption-setting primarily using summary indicator } \\
\text { assumptions (e.g. the TFR). Example projections for the } \\
\text { local government area of Noosa, Australia, are shown. }\end{array}$ \\
\hline $\begin{array}{l}\text { Wilson, T. (2016). Evaluation of } \\
\text { alternative cohort-component models } \\
\text { for local area population forecasts. } \\
\text { Population Research Policy Review, } \\
\text { 35(2), 241-261. } \\
\text { https://doi.org/10.1007/s11113-015- } \\
9380-\mathrm{y}\end{array}$ & $\begin{array}{l}\text { The author describes an evaluation of five types of cohort- } \\
\text { component model, which differ in the way they include } \\
\text { migration. Retrospective forecasts for } 67 \text { local government } \\
\text { areas of New South Wales, Australia, were produced for the } \\
\text { projection horizon } 1991 \text { to } 2011 \text {, and the results compared } \\
\text { to actual population estimates. Two sets of forecasts were } \\
\text { prepared: (i) unconstrained forecasts and (ii) forecasts } \\
\text { constrained to population totals from an extrapolative } \\
\text { model. The constrained forecasts proved considerably more } \\
\text { accurate; the constrained bi-regional model gave the most } \\
\text { accurate age-specific forecasts (by a small margin). }\end{array}$ \\
\hline
\end{tabular}




\begin{tabular}{|c|c|}
\hline Reference and URL & Key points \\
\hline $\begin{array}{l}\text { Wilson, T. (2017b). Does averaging } \\
\text { yield more accurate local and regional } \\
\text { population forecasts? Applied Spatial } \\
\text { Analysis and Policy, 10(4), 497-513. } \\
\text { https://doi.org/10.1007/s12061-016- } \\
\underline{9194-2}\end{array}$ & $\begin{array}{l}\text { The paper reports an evaluation of the Constant Share of } \\
\text { Population - Variable Share of Growth (CSP-VSG) } \\
\text { averaged model for forecasting total populations. It was } \\
\text { applied to SA2, SA3 and SA4 geographies of Australia } \\
\text { (median populations about 9,000, 57,000 and 224,000, } \\
\text { respectively) over several } 10 \text { year forecast horizons. } \\
\text { Comparisons were made with published population } \\
\text { estimates and forecasts from a simple linear extrapolation. } \\
\text { The CSP-VSG model outperformed the linear model and } \\
\text { gave respectable levels of accuracy. Median Absolute } \\
\text { Percentage Errors were 6-8\% for SA2s, 3-6\% for SA3s and } \\
2-4 \% \text { for SA4s after } 10 \text { years. }\end{array}$ \\
\hline $\begin{array}{l}\text { Wilson, T., \& Rowe, F. (2011). The } \\
\text { forecast accuracy of local government } \\
\text { area population projections: a case } \\
\text { study of Queensland. The Australasian } \\
\text { Journal of Regional Studies, 17(2), } \\
\text { 204-243. } \\
\text { https://www.anzrsai.org/assets/Uploads } \\
\text { PublicationChapter/464- } \\
\text { WilsonandRowe.pdf }\end{array}$ & $\begin{array}{l}\text { The authors present an analysis of the accuracy of seven } \\
\text { past rounds of official local government area population } \\
\text { projections for Queensland, Australia. Error was found to } \\
\text { be positively associated with projection horizon length and } \\
\text { negatively associated with population size. Areas with large } \\
\text { Indigenous populations and areas with lots of mining } \\
\text { activity were particularly poorly forecast. Overall, the } \\
\text { projections were more accurate than forecasts obtained by } \\
\text { simple linear extrapolation. }\end{array}$ \\
\hline $\begin{array}{l}\text { Wilson, T., Brokensha, H., Rowe, F., } \\
\& \text { Simpson, L. (2018). Insights from } \\
\text { the evaluation of past local area } \\
\text { population forecasts. Population } \\
\text { Research Policy Review, 37(1), 137- } \\
155 . \\
\text { https://doi.org/10.1007/s11113-017- } \\
9450-4\end{array}$ & $\begin{array}{l}\text { The authors present an evaluation of local area projections } \\
\text { produced by State/Territory governments in Australia over } \\
\text { the last } 30 \text { years for forecast horizons of } 5,10,15 \text { and } 20 \\
\text { years ahead. Forecast errors were found to be high for areas } \\
\text { with the smallest populations, especially those with } \\
\text { populations under } 2,000 \text {. The concept of a forecast 'shelf } \\
\text { life' is introduced, defined as "how far into the future a } \\
\text { forecast is likely to remain within a certain error margin". } \\
\text { Shelf lives are calculated from past errors as the number of } \\
\text { years ahead the error of } 80 \% \text { of local area forecasts } \\
\text { remained within } 10 \% \text { absolute percentage error. This varies } \\
\text { greatly by jump-off population size. Empirical prediction } \\
\text { intervals are also calculated and applied to recent forecast } \\
\text { examples. }\end{array}$ \\
\hline $\begin{array}{l}\text { Wu, B., \& Birkin, M. (2013). Moses: } \\
\text { A Dynamic Spatial Microsimulation } \\
\text { Model for Demographic Planning. In } \\
\text { R. Tanton \& K. Edwards (Eds.), } \\
\text { Spatial Microsimulation: A Reference } \\
\text { Guide for Users (pp. 171-193). } \\
\text { Springer Netherlands. } \\
\text { https://doi.org/10.1007/978-94-007- } \\
4623-7 \text { 11 }\end{array}$ & $\begin{array}{l}\text { This book chapter discusses the benefits of microsimulation } \\
\text { methods for the modelling of detailed individual } \\
\text { characteristics, and the ability of dynamic microsimulation } \\
\text { models to update and project the characteristics of } \\
\text { populations of individuals. The authors introduce Moses, a } \\
\text { dynamic microsimulation model which allows for detailed } \\
\text { forecasts at the small area level. Moses simulates the UK } \\
\text { population over the period from } 2001 \text { to } 2031 . \text { The } \\
\text { modelling approach is described and visualisations are } \\
\text { provided for projected changes in age-sex structure, } \\
\text { mortality, and student populations. }\end{array}$ \\
\hline
\end{tabular}




\begin{tabular}{|c|c|}
\hline Reference and URL & Key points \\
\hline $\begin{array}{l}\text { Wu, B. M., Birkin, M. H., \& Rees, P. } \\
\text { H. (2010). A Dynamic MSM With } \\
\text { Agent Elements for Spatial } \\
\text { Demographic Forecasting. Social } \\
\text { Science Computer Review, 29(1), 145- } \\
\text { 160. } \\
\text { https://doi.org/10.1177/089443931037 } \\
\underline{0113}\end{array}$ & $\begin{array}{l}\text { In this paper the authors work to develop Moses, a dynamic } \\
\text { microsimulation model of the UK which simulates } \\
\text { populations at the individual level at a small area level, to } \\
\text { support policy and decision making. They demonstrate the } \\
\text { use of Moses in two experiments. First, they describe how } \\
\text { Moses can be used to model the migration of higher } \\
\text { education students, with consideration for the students' } \\
\text { education level. Second, the authors describe how their } \\
\text { method allows personal history to be used to support the } \\
\text { projection of mortality, enabling characteristics such as a } \\
\text { person's work history or previous places of residence to be } \\
\text { used to calculate their mortality/morbidity probabilities. }\end{array}$ \\
\hline $\begin{array}{l}\text { Xanthos, G., Ladias, C. A., \& } \\
\text { Genitsaropoulos, C. (2013). A method } \\
\text { for forecasting population changes in } \\
\text { alpine, semi-alpine and lowland } \\
\text { communities of Epirus region in } \\
\text { Greece. Regional Science Inquiry } \\
\text { Journal, 1, 173-179. } \\
\text { http://www.rsijournal.eu/ARTICLES/J } \\
\text { une_2013/11.pdf }\end{array}$ & $\begin{array}{l}\text { The authors report an evaluation of share of population and } \\
\text { share of population growth models, including the authors' } \\
\text { preferred shift-share model, to predict small area } \\
\text { populations in communities within the Epirus region in } \\
\text { Greece. The populations of communities proved difficult to } \\
\text { predict for all of these methods, with all MAPEs being } \\
>20 \% \text { for a } 10 \text { year forecast horizon (though the small area } \\
\text { population sizes are not stated). }\end{array}$ \\
\hline $\begin{array}{l}\text { Zhang, J. L., \& Bryant, J. (2020). } \\
\text { Bayesian disaggregated forecasts: } \\
\text { internal migration in Iceland. In S. } \\
\text { Mazzuco, \& N. Keilman (Eds.), } \\
\text { Developments in Demographic } \\
\text { Forecasting (pp. 193-215). Springer. } \\
\text { https://doi.org/10.1007/978-3-030- } \\
42472-5 \_10 \\
\end{array}$ & $\begin{array}{l}\text { Estimates and forecasts of internal migration by age and sex } \\
\text { at the local level are important for local planning, but small } \\
\text { counts and erratic patterns can make using traditional } \\
\text { methods difficult. The authors present a Bayesian } \\
\text { modelling strategy for estimating age-sex patterns of } \\
\text { internal migration in Iceland. The model includes effects } \\
\text { for age, sex, time, region and various interaction effects. }\end{array}$ \\
\hline $\begin{array}{l}\text { Zoraghein, H., \& O'Neill, B. C. } \\
\text { (2020a). A spatial population } \\
\text { downscaling model for integrated } \\
\text { human-environment analysis in the } \\
\text { United States. Demographic Research, } \\
\text { 43, 1563-1606. } \\
\text { https://doi.org/10.4054/DemRes.2020. } \\
\underline{43.54}\end{array}$ & $\begin{array}{l}\text { The authors describe an evaluation of a model which } \\
\text { disaggregates US state populations to } 1 \mathrm{~km}^{2} \text { grid squares. A } \\
\text { gravity-type model was used for the downscaling, specified } \\
\text { individually for each state and for its rural/urban } \\
\text { population. Forecast population increase was allocated to } \\
\text { grid cells proportional to its modelled 'suitability for } \\
\text { growth' based on many variables (with decrease distributed } \\
\text { to the inverse of its suitability). An evaluation was } \\
\text { undertaken by 'forecasting' from } 2000 \text { to } 2010 \text { and } \\
\text { comparing forecasts with actual } 2010 \text { population estimates. } \\
\text { Lower errors were found for urban grid square projections } \\
\text { with larger populations. }\end{array}$ \\
\hline
\end{tabular}




\begin{tabular}{|l|l|}
\hline Reference and URL & Key points \\
\hline Zoraghein, H., \& O’Neill, B. C. & The authors describe how small area population forecasts \\
(2020b). US State-level Projections of & for the contiguous US were prepared for the horizon 2010- \\
the Spatial Distribution of Population & 2100. A gravity-based model (as described in Zoraghein \\
Consistent with Shared Socioeconomic & and O’Neill 2020a) was used to distribute State population \\
Pathways. Sustainability, 12(8), 3374. & forecasts consistent with three of the Shared Socioeconomic \\
https://doi.org/10.3390/su12083374 & Pathways to $1 \mathrm{~km}^{2}$ grid squares. \\
\hline
\end{tabular}

